Prepared in Cooperation with

STATE OF NEVADA DEPARTMENT OF CONSERVATION AND NATURAL RESOURCES, DIVISION OF

WATER RESOURCES, ELKO COUNTY, EUREKA COUNTY, HUMBOLDT COUNTY, AND WASHOE COUNTY

\title{
Evaluation of Precipitation Estimates from PRISM for the 1961-90 and 1971-2000 Data Sets, Nevada
}

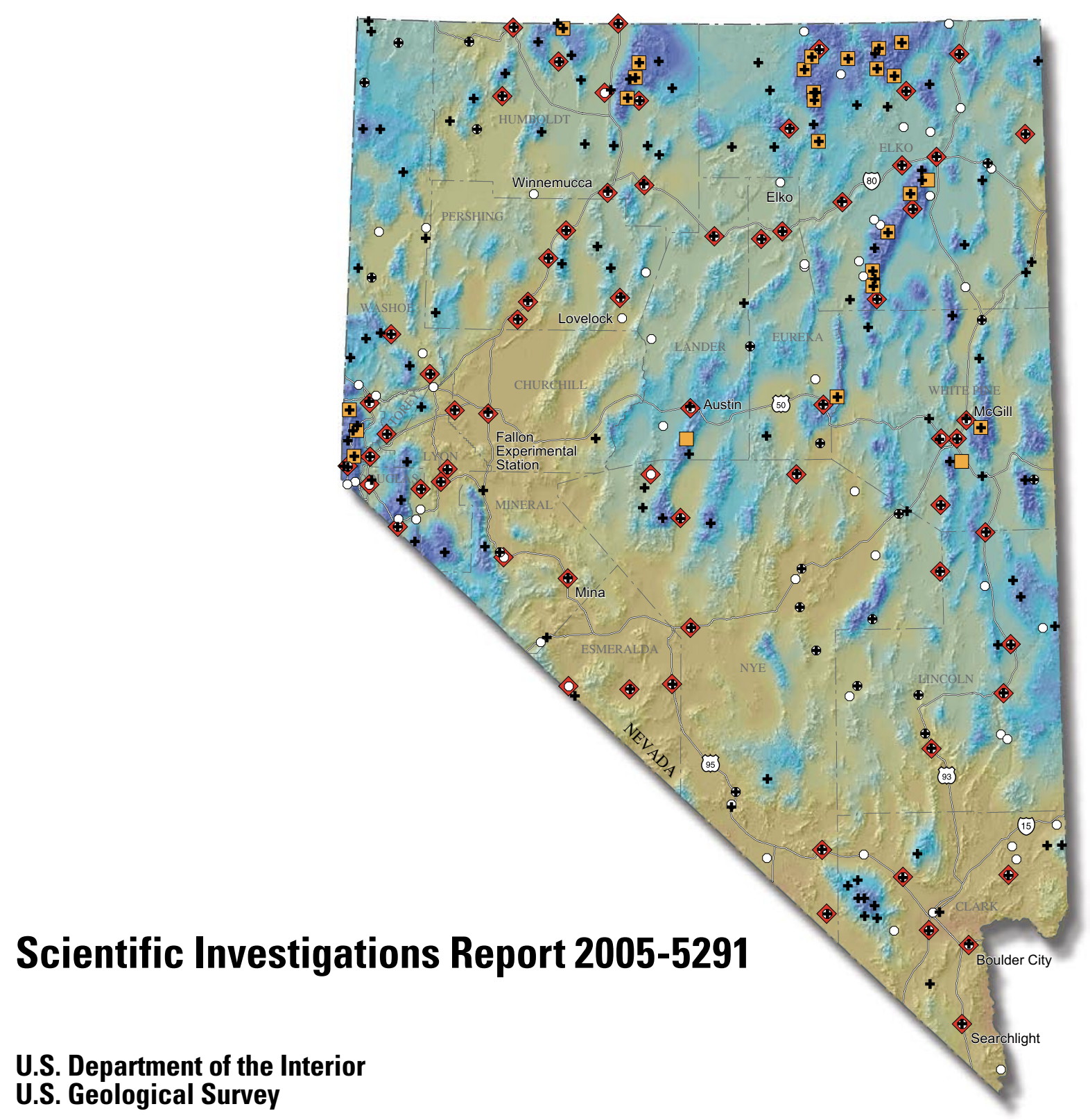


Cover: Precipitation estimated using PRISM model, location of PRISM control points and climate stations in Nevada. 


\section{Evaluation of Precipitation Estimates from PRISM for the 1961-90 and 1971-2000 Data Sets, Nevada}

By Anne E. Jeton', Sharon A. Watkins' ${ }^{1}$, Thomas J. Lopes' ${ }^{1}$, and Justin Huntington ${ }^{2}$

Prepared in Cooperation with

STATE OF NEVADA DEPARTMENT OF CONSERVATION AND NATURAL RESOURCES,

DIVISION OF WATER RESOURCES, ELKO COUNTY, EUREKA COUNTY, HUMBOLDT COUNTY,

AND WASHOE COUNTY

Scientific Investigations Report 2005-5291

U.S. Department of the Interior

U.S. Geological Survey

${ }^{1}$ U.S. Geological Survey

${ }^{2}$ Desert Research Institute 


\section{U.S. Department of the Interior \\ Gale A. Norton, Secretary}

\section{U.S. Geological Survey \\ P. Patrick Leahy, Acting Director}

Use of trade, product, or firm names in this report is for identification purposes only and does not constitute endorsement by the U.S. Geological Survey.

Carson City, Nevada, 2006

For additional information write to:

U.S. Geological Survey

Director, USGS Nevada Water Science Center

333 West Nye Lane, Room 203

Carson City, NV 89706-0866

Email: GS-W-NVpublic-info@usgs.gov

URL: http://nevada.usgs.gov/

For more information about the USGS and its products:

Telephone: 1-888-ASK-USGS

World Wide Web: http://www.usgs.gov/

Although this report is in the public domain, permission must be secured from the individual copyright owners to reproduce any copyrighted materials contained within this report.

Scientific Investigations Report 2005-5291, Version 2.0 


\section{Contents}

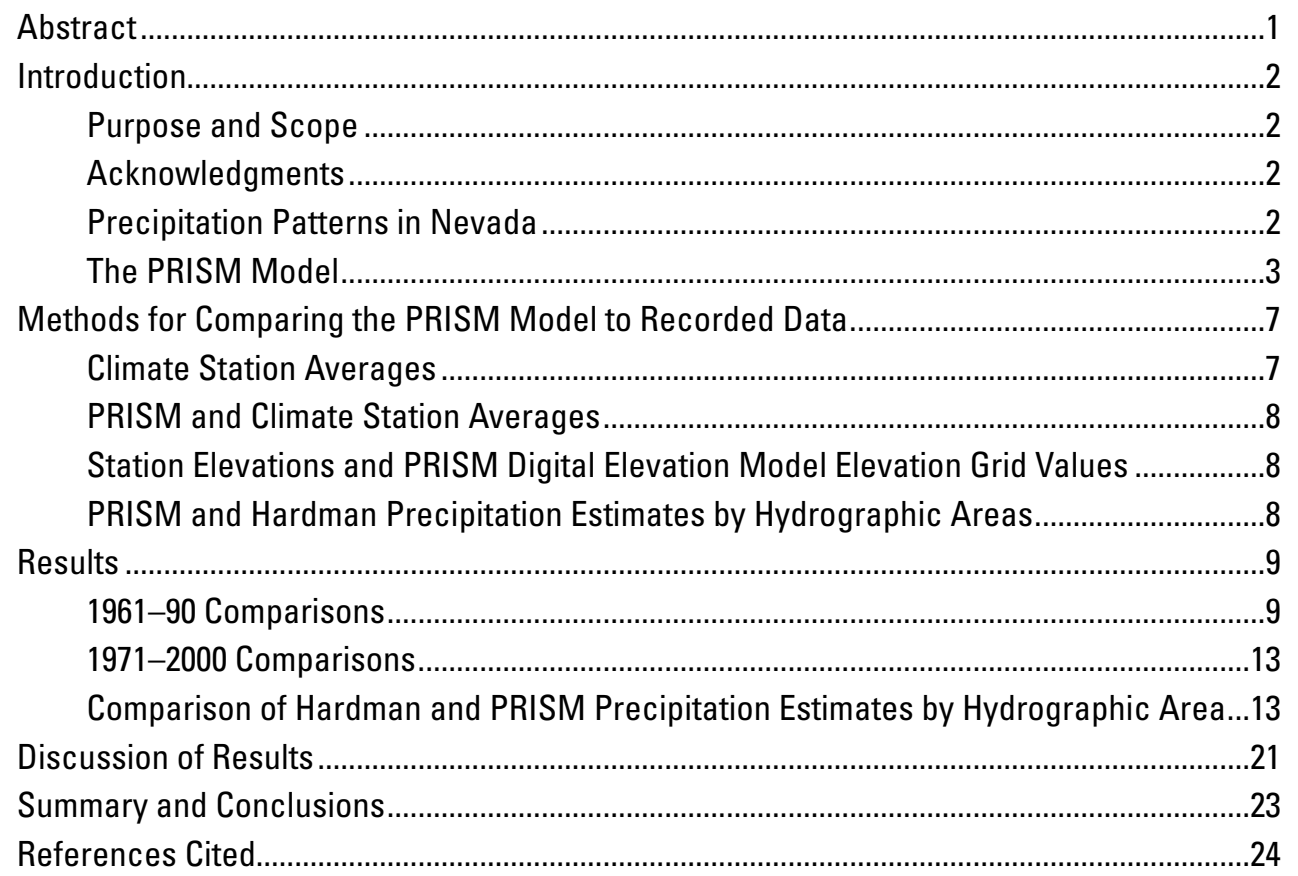

\section{Figures}

Figure 1. Precipitation estimated using PRISM model, location of PRISM control points and climate stations in Nevada.

Figure 2. National Weather Service long-term annual precipitation for selected climate stations in Nevada: (A) Austin, (B) Boulder City, (C) Elko, (D) Fallon, (E) Mina, (F) McGill, (G) Lovelock, (H) Searchlight, and (I) Winnemucca.

Figure 3. Percent difference and absolute differences between PRISM estimated precipitation and National Weather Service and Western Regional Climate Center recorded data for 1961-90 and 1971-2000 periods

Figure 4. Scatter plot of relation between recorded precipitation for National Weather Service and Western Regional Climate Center sites and percent difference (A) and absolute difference (B) between PRISM estimated precipitation and the recorded precipitation for the 1961-90 period.

Figure 5. Scatter plot of relation between actual station elevation and percent difference (A) and absolute difference (B) between PRISM estimated precipitation and the recorded precipitation for the $1961-90$ period.

Figure 6. Percent difference between estimated PRISM precipitation values and National Weather Service recorded data for the 1961-90 period

Figure 7. Percent difference between estimated PRISM precipitation values and the Western Regional Climate Center recorded data for the 1961-90 period

Figure 8. Scatter plot of relation between recorded precipitation for National Weather Service, Western Regional Climate Center, and SNOTEL monitoring sites and percent difference (A) and absolute difference (B) between PRISM estimated precipitation and the recorded precipitation for the 1971-2000 period 
Figure 9. Scatter plot of relation between actual station elevation and percent difference (A) and absolute difference (B) between PRISM estimated precipitation and the recorded precipitation for National Weather Service, Western Regional

Climate Center, and SNOTEL monitoring sites for the 1971-2000 period.

Figure 10. Percent difference between estimated PRISM precipitation values and National Weather Service recorded data for the 1971-2000 period

Figure 11. Percent difference between estimated PRISM precipitation values and the Western Regional Climate Center and Natural Resources Conservation Service SNOTEL recorded data for the 1971-2000 period.

Figure 12. Percent difference between estimates of average annual precipitation in hydrographic areas using PRISM precipitation values and Hardman estimates for the 1961-90 period 20

Figure 13. Scatter plots showing relation between Hardman estimates of annual precipitation calculated for hydrographic areas in Nevada and PRISM estimates for 1961-90 and 1971-2000.

\section{Tables}

Table 1. Summary statistics of percent difference between the PRISM precipitation data and the recorded data sets for the 1961-90 and 1971-2000 periods .7

\section{Appendixes}

\section{Appendixes may be found in separate PDF files, linked below.}

Appendix 1. Climate stations used to evaluate PRISM precipitation estimates for the State of Nevada. Data obtained from the Western Regional Climate Center (includes the National Weather Service data) and the Natural Resources Conservation Service SNOTEL network

Appendix 2. Recorded and PRISM estimated precipitation at climate stations in Nevada. Data obtained from WRCC and NRCS

Appendix 3. Actual and estimated elevations for climate stations and associated percent differences

Appendix 4. Percent differences between PRISM estimates and National Weather Service normals, and Western Regional Climate Center, and Natural Resources Conservation Service averages for individual climate stations

Appendix 5. Estimates of annual precipitation for hydrographic areas in Nevada based on PRISM and Hardman maps, and associated percent differences 


\section{Conversion Factors}

\begin{tabular}{lcl}
\hline \multicolumn{1}{c}{ Multiply } & By & \multicolumn{1}{c}{ To obtain } \\
\hline inch (in.) & Length & \\
inch (in.) & 2.54 & centimeter $(\mathrm{cm})$ \\
foot (ft) & 25.4 & millimeter $(\mathrm{mm})$ \\
mile (mi) & 0.3048 & meter $(\mathrm{m})$ \\
mile, nautical (nmi) & 1.609 & kilometer $(\mathrm{km})$ \\
yard (yd) & 1.852 & kilometer $(\mathrm{km})$ \\
\hline & 0.9144 & meter (m) \\
\hline acre & Area & \\
acre & 4,047 & square meter $\left(\mathrm{m}^{2}\right)$ \\
acre & 0.4047 & hectare (ha) \\
acre & 0.4047 & square hectometer $\left(\mathrm{hm}^{2}\right)$ \\
square foot $\left(\mathrm{ft}^{2}\right)$ & 0.004047 & square kilometer $\left(\mathrm{km}^{2}\right)$ \\
square foot $\left(\mathrm{ft}^{2}\right)$ & 929.0 & square centimeter $\left(\mathrm{cm}^{2}\right)$ \\
square inch $\left(\mathrm{in}^{2}\right)$ & 0.09290 & square meter $\left(\mathrm{m}^{2}\right)$ \\
section $\left(640 \mathrm{acres}^{2}\right.$ or 1 square mile) & 6.452 & square centimeter $\left(\mathrm{cm}^{2}\right)$ \\
square mile $\left(\mathrm{mi}^{2}\right)$ & 259.0 & square hectometer $\left(\mathrm{hm}^{2}\right)$ \\
square mile $\left(\mathrm{mi}^{2}\right)$ & 259.0 & hectare (ha) \\
\hline
\end{tabular}

Horizontal coordinate information is referenced to "North American Datum of 1927 (NAD 27)." 


\title{
Evaluation of Precipitation Estimates from PRISM for the 1961-90 and 1971-2000 Data Sets, Nevada
}

\author{
By Anne E. Jeton', Sharon A. Watkins', Thomas J. Lopes', and Justin Huntington ${ }^{2}$
}

\section{Abstract}

The Oregon Climate Service estimated precipitation in Nevada for two 30-year periods, 1961-90 and 1971-2000, using the computer program, Parameter-elevation Regressions on Independent Slopes Model, or PRISM. The accuracy of PRISM estimates for Nevada has not been evaluated statewide relative to known observation points. The intent of the PRISM model is not to specifically match simulated precipitation amounts to recorded station data, but rather to model large-scale orographic processes. This allows for interpolation to locations beyond the recorded data set assuming those locations have similar physiographic and climatic properties. PRISM provides spatially-estimated averages of long-term precipitation that sometimes are not well correlated to known measured points. The known measuring points do not have associated accuracy ratings, and the PRISM model does not include prediction error relative to the station record. Consequently, for this report a difference of \pm 15 percent relative to the recorded data was selected as an acceptable range of error or difference. Two data sets were compiled and used in this study to compare recorded precipitation to PRISM precipitation estimates for the 1961-90 and the 1971-2000 periods, and to the National Weather Service normals and the Western Regional Climate Center averages. The National Weather Service normals, however, are considered to be the most accurate reporting of the 30-year means for both the 1961-90 and the 1971-2000 periods. For the earlier and latter periods respectively, 89 and 85 percent of PRISM estimates were within the acceptable range of error for the National Weather Service data set and 63 and 70 percent were within the acceptable range of error for the Western Regional Climate Center data. However, the percent differences are higher when comparing PRISM estimates to recorded data from some of the highelevation SNOpack TELemtry (SNOTEL) sites and to sites in the 5,500 to 7,500 feet elevation zone.

A statistical difference does not exist at the 95 percent confidence level between the two 30-year National Weather Service means, nor between the 1961-90 National Weather Service and the Western Regional Climate Center averages, hence these two data sets are considered interchangeable. There are, however, statistically significant differences between all combinations of the recorded data sets and the

1 U.S. Geological Survey

2 Desert Research Institute
PRISM estimates. In general, the percent differences between the PRISM estimates and the National Weather Service 30year normals have the narrowest interquartile ranges and the narrowest overall ranges.

Statistical tests using three elevation data sets indicate no significant difference between the U.S. Geological Survey National Elevation Data 30-meter digital elevation model and the PRISM 4-km digital elevation model; however, there are differences between the actual station elevations and the digital elevation model data sets. In general, the larger the elevation difference, the greater the precipitation difference. The largest absolute differences for both the National Weather Service and Western Regional Climate Center data sets coincide with elevation differences of 1,000 feet or more. The spread in differences increases noticeably between the 4,500 feet-8,000 feet range for both National Weather Service and Western Regional Climate Center data. Some of the individual sites with a difference exceeding 25 percent have location or elevation input errors.

There appears to be little correlation between precipitation estimate differences and latitude and longitude.

Mean precipitation volumes using the Hardman precipitation zone map for each of the 232 hydrographic areas in Nevada were compared to the PRISM precipitation volumes for both of the 30-year periods. PRISM estimates of the amount of precipitation for hydrographic areas in the midsection of the State were as much as 37 percent lower than estimates made using the Hardman map. For the northeastern and some areas in the southeastern part of the State, PRISM estimates are within 5 percent of the Hardman estimates. For much of the State outside the central region, PRISM estimates are from 6 to 155 percent greater than precipitation estimates made using the Hardman map. Typically, PRISM estimates correlate best with Hardman volumes for those hydrographic areas with elevations in the 4,000-9,000 feet range.

In comparing the two 30-year periods climatologically, the 1961-90 period has a mix of negative and positive Pacific Decadal Oscillations, a decadal-scale pattern of climate variability that may be more representative for long-term analyses. The distribution of differences between the PRISM data and the recorded data may be the result of overinterpolation between the limited data points, input error in location and station elevation, and possibly the weight given the hypothesis 
that precipitation is linearly related to elevation. The precipitation-elevation relations used in PRISM may not be appropriate for all mountainous areas, particularly for leeward slopes. The coarseness of the PRISM grid cells, coupled to the sparseness of the long-term precipitation data and the broad range of differences between PRISM estimates and the recorded data, suggest the optimum use for this data set is regional.

\section{Introduction}

Nevada is the driest of all States, making water an extremely valuable resource to sustain agriculture, industry, mining, and rapid urban growth. Much of the State depends on ground water because few rivers and streams are perennial. Regional water budgets have been developed for much of the State using average annual precipitation to estimate the amount of ground-water recharge (the fraction of precipitation that reaches the water table).

The distribution of precipitation typically is estimated from either long-term precipitation rates generally determined from data interpolated from recorded sites with poorly known accuracy, from isohyetal precipitation maps (Hardman and Mason, 1949; Hardman, 1965), or more recently from computer modeled precipitation data (Daly and others, 1994). Reconnaissance-scale water budgets for Nevada used the Hardman and Mason map (1949; Maxey and Eakin, 1949; Eakin and others, 1965; Eakin, 1961). More recent studies by the U.S. Geological Survey (USGS; Berger, 2000a and 2000b; Nichols, 2000) used 30-year averages generated from the computer program Parameter-elevation Regressions on Independent Slopes Model (PRISM; Daly and others, 1994; Oregon Climate Service, 2004). The Hardman and Mason (1949) and Hardman (1965) isohyetal map are based on the distribution of vegetation communities in the State and precipitation data collected during the first decades of the 1900s. PRISM is based on the relation between elevation, slope, aspect and the average precipitation for 1961-90 and 1971-2000. Hydrologic reconnaissance studies of the 1960-70s (Eakin, 1961; Eakin and others, 1965) estimated recharge using precipitation data from the Hardman and Mason (1949) and Hardman (1965) maps. Recent estimates of recharge (Berger, 2000a and 2000b) used the PRISM precipitation map which generally estimates more precipitation than the Hardman (1965) map. As a result, revised estimates of recharge in eastern and north-central Nevada (Nichols, 2000; Berger, 2000a) are about 2 to 2.5 times greater than the earlier hydrologic reconnaissance studies. The accuracy of PRISM estimates for Nevada, however, has not been evaluated statewide relative to measured (or recorded) precipitation. Evaluating the accuracy of precipitation estimates made using the PRISM model are needed to evaluate the accuracy of the recharge estimates. Such an evaluation would be useful for assessing aquifer vulnerability (the susceptibility of the aquifer to contamination by recharge), climate diagnostics, streamflow estimation, and other hydrologic, climatic, and atmospheric applications.

\section{Purpose and Scope}

This report evaluates the accuracy of PRISM precipitation estimates for Nevada relative to known observation points. This evaluation quantifies the differences associated with PRISM precipitation estimates; identifies areas of Nevada where PRISM over-, under-, or closely estimates recorded precipitation; and compares statewide estimates of precipitation for hydrographic areas using the Hardman (1965) and PRISM maps.

\section{Acknowledgments}

This study was funded as part of a cooperative agreement between the U.S. Geological Survey (USGS) and by a number of cooperators including, the Nevada Department of Conservation and Natural Resources Division of Water Resources, Barrick Goldstrike Mining Inc., Elko, Eureka, Humboldt and Washoe Counties; and the Humboldt River Basin Water Authority.

\section{Precipitation Patterns in Nevada}

Precipitation in Nevada is temporally and spatially highly variable, ranging from less than 5 in. to more than 40 in., with an overall average of $9.5 \mathrm{in}$. when weighing each climate division's precipitation by area (Western Regional Climate Center, 2005a). The two seasonal weather patterns that bring precipitation to Nevada are broadly referred to as winter cold fronts and summer monsoons (Houghton and others, 1975). During winter, prevailing westerly winds push cold fronts originating in the Gulf of Alaska across Nevada. Cold fronts typically are long-duration, low-intensity, broad storms that mostly cross northern Nevada yielding relatively low amounts of precipitation. The important precipitation-bearing storms that augment the mountain snowpack are more often cold fronts coupled to more moisture-laden southerly Pacific air flow. During summer, prevailing winds bring monsoonal moisture from the Gulfs of Mexico and California. Monsoons typically are shortduration, high-intensity, localized thunderstorms that are more common in southern and eastern Nevada than in the western part of the State. Relatively few cold fronts reach southern Nevada. Months without precipitation are common between the winter cold fronts and the summer monsoons. A precipitation maximum occurs in the western and south-central parts of the State during winter, in the central and northeastern parts during spring, and primarily in the eastern part during summer. Average annual precipitation is least in the valleys, ranging from less than $5 \mathrm{in}$. in the southern valleys to $18 \mathrm{in.} \mathrm{in}$ 
Lamoille Canyon on the western side of the Ruby Mountains in northwestern Nevada, to more than 30 in. along the Ruby Mountains crest, and more than 40 in. in the Sierra Nevada (Western Regional Climate Center, 2005b).

Several climate stations in Nevada (fig. 1; Austin, Boulder City, Fallon Experimental Station, Elko, Mina, McGill, Lovelock, Searchlight, and Winnemucca) have nearly continuous records of precipitation for the past 60 to $100 \mathrm{yrs}$ (fig. 2 ). Periods of above and below average precipitation last on average from 2 to $10 \mathrm{yrs}$. Statistical tests to determine whether differences exist in mean monthly precipitation between the nine sites listed in figure 2, for the two 30-yr periods represented by the PRISM data sets (1961-90 and 1971-2000), and two earlier periods (1916-1945 and 1921-1950) suggests little to no difference with one exception. For both 30-yr periods, statistical data for Mina, in west-central Nevada, indicates a statistically significant upward trend in precipitation with time, at 95 percent confidence level for all months. The other eight long-term stations have statistically significant wetter summer months for the periods 1961-90 and 1971-2000 than for the periods prior to 1961 .

The influence of multi-decadal scale regional climate patterns on the western United States may address some of the problems associated with using 30-yr average precipitation values for hydrologic applications. The Pacific Decadal Oscillation (PDO; Mantua and others, 1997) is a decadal-scale El Niño-like pattern of Pacific climate variability. El Niño and La Niña are large-scale oceanic warming and cooling trends, respectively, in the tropical Pacific Ocean affecting global atmospheric circulation patterns (National Oceanic and Atmospheric Administration, 2005). Two characteristics distinguish the PDO from El Niño; PDO persists for 20-30 yrs with a climatic signature most visible in the North Pacific/ North American sector of the globe (thus influencing climate patterns in the western United States), whereas El Niño events persist for 6 to 18 months with a climate signature in the tropical Pacific Ocean. PDOs are described as either negative (cool or more La Niña-like, where the eastern tropical Pacific surface temperature are below-average and the northwest United States typically wetter) or positive (warm, resembling El Niño conditions). A positive PDO is characterized by periods of exceptionally warm ocean surface temperatures across the eastern tropical Pacific Ocean, resulting in slightly warmer and typically dryer conditions in the northwestern United States. A positive PDO does not imply exclusively El Niño-like weather patterns, but rather El Niños are more common during these periods and potentially stronger than otherwise (Michael Dettinger, USGS, written commun., 2001). PDO variability is strongly expressed in regional snowpack and streamflow anomalies, especially in western North America (Cayan, 1996; Dettinger and others, 1998; Dettinger and others, 2004; Stewart and others, 2005).

From 1948-76, Nevada and the western United States were in a La Niña-like period (cooler, wetter PDO), but from 1977-98, the PDO shifted to a warmer phase. Thus, the 196190 period includes 16 years of negative PDO and 14 years of a positive PDO. This period is regarded as an even mix of the range of $\mathrm{PDO}$ regimes of western United States climates. In contrast, the 1971-2000 period includes 8 La Niña-like PDO years (1971-76) and 22 El Niño-like PDO years. The past five years suggest a return to a La Niña-like PDO, though that is currently being debated by the atmospheric science community. One difference between the La Niña and the El Niño phases is in the frequency that storms approach from different directions. The PRISM regression focuses on data from similar topographic aspects, thus there may be a tendency to bias the training period in one wind direction or another. This may, in turn, bias the long-term mean results if the PRISM data are used for a period that has a different PDO signature than for the training period used to develop the PRISM data set. From a long-term perspective, the 1961-90 period with its mix of PDO regimes is perhaps the most applicable for current day use.

The spatial distribution of precipitation in Nevada is strongly influenced by latitude and elevation (Houghton and others, 1975). In general, precipitation increases with latitude and elevation; however, multiple storm tracts and rain-shadow effects on the leeward side of most western and north-central Nevada mountain ranges adds uncertainty to using simple linear precipitation/elevation relations. The most important variable influencing the distribution of precipitation is continentality (Houghton and others, 1975), which is more commonly called the rain-shadow effect. In Nevada, the prevailing winds are from the west, and as moist air from the Pacific Ocean ascends the western (windward) slopes of the Sierra Nevada and Cascade Range, the air cools, condensation takes place and precipitation occurs. Air descending the eastern (leeward) side of the mountains is warmed by compression and very little precipitation occurs.

The spatial distribution of average annual precipitation was estimated by Hardman and Mason (1949), Hardman (1965) and later by Daly and others (1994), and the Oregon Climate Service (2004). Hardman mapped isohyetal contours (bands of equal precipitation) based on the distribution of vegetation communities, topography, and precipitation data collected during the early 1900s. Lacking measured precipitation data at the higher elevations, Hardman and Mason (1949) assigned areas above 9,000 ft as having precipitation greater than 20 in. Data collected since the 1980's from high-elevation SNOTEL stations indicate that average annual precipitation is about 25-50 in. for the higher elevation zones.

\section{The PRISM Model}

The PRISM model uses precipitation data from weather stations, elevation data in the form of a digital elevation model (DEM) at a 4-km grid cell resolution, and other spatial data sets in a statistical-geographic framework. Mean annual precipitation values are derived from estimates of 30-yr monthly averages. Based on the premise that, for a localized region, elevation is the most important factor in the distribution of 


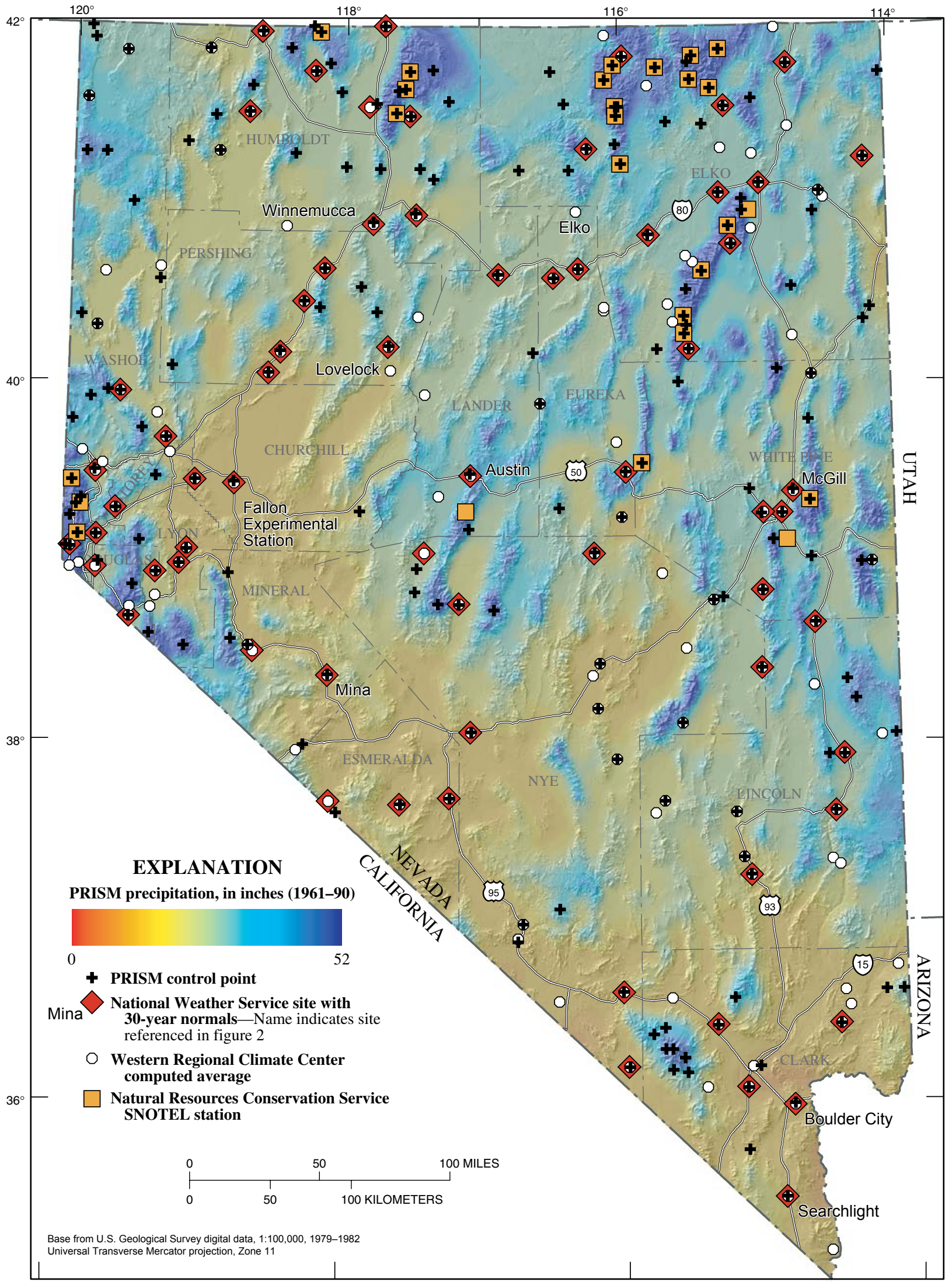

Figure 1. Precipitation estimated using PRISM model, location of PRISM control points and climate stations in Nevada. 


\section{A Austin}

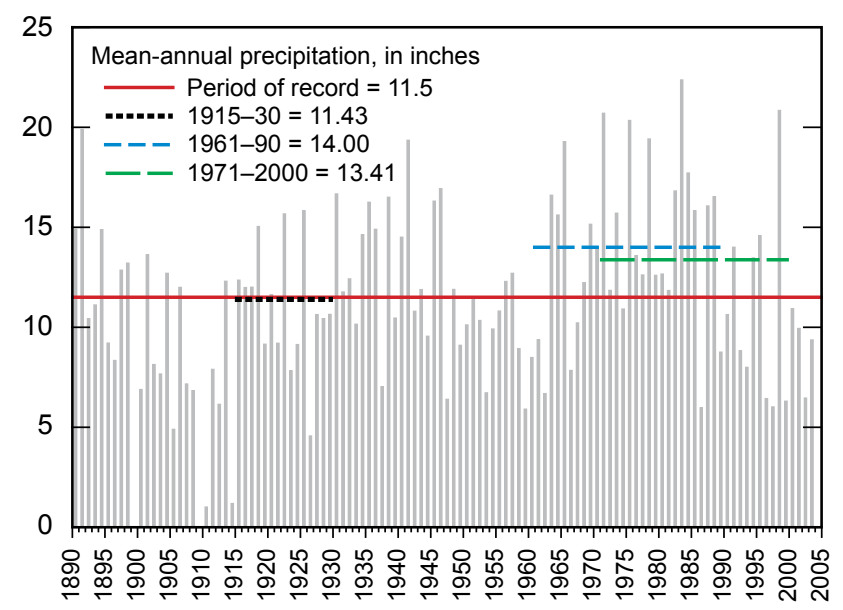

\section{B Boulder City}

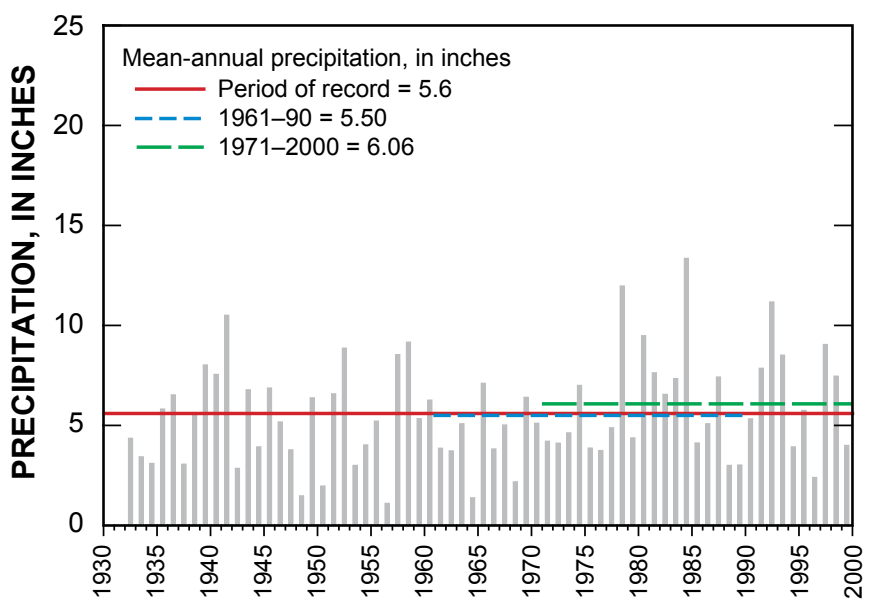

\section{Elko Airport}

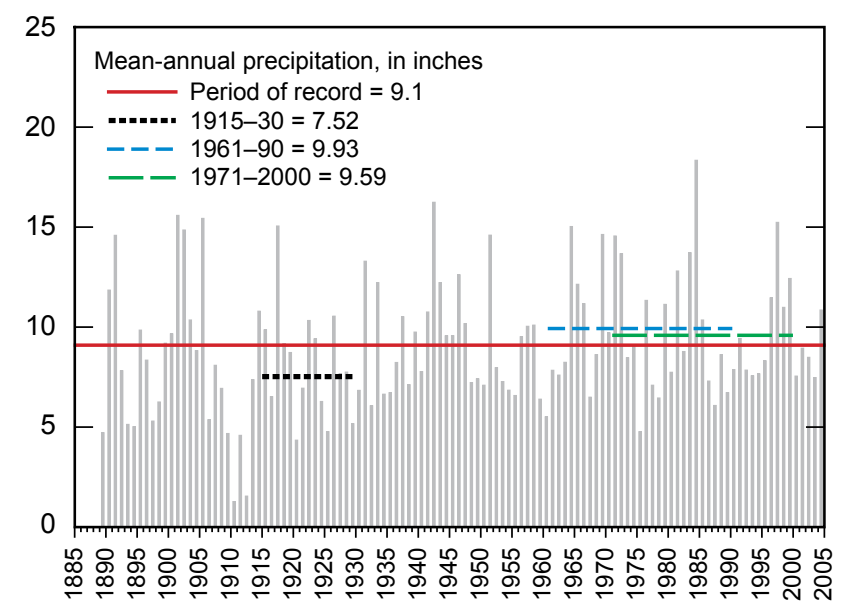

\section{Fallon Experimental Station}

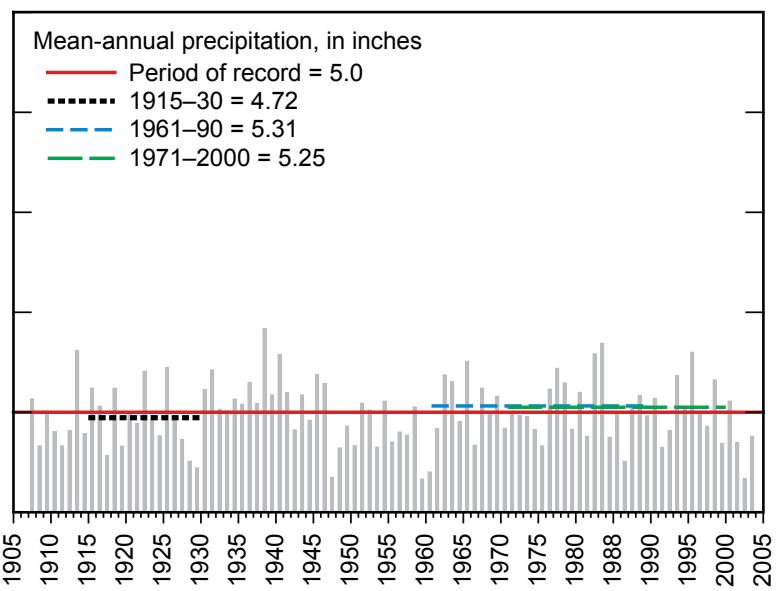

E Mina

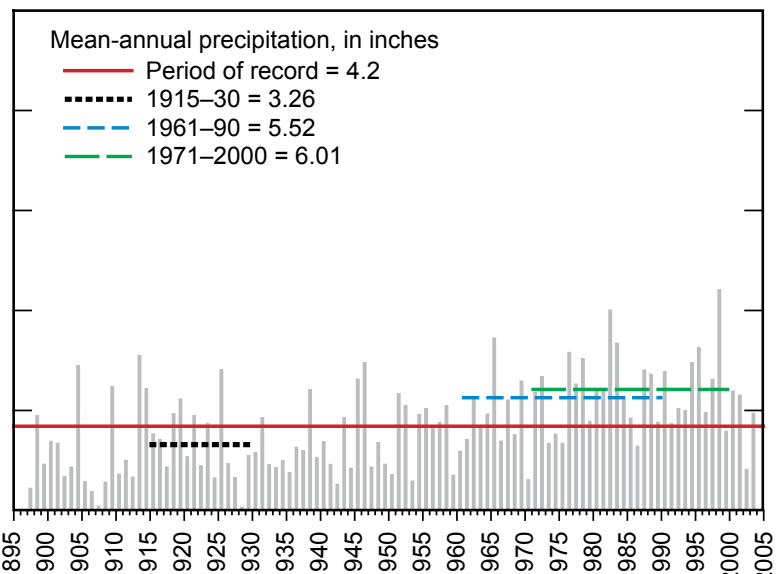

F McGill

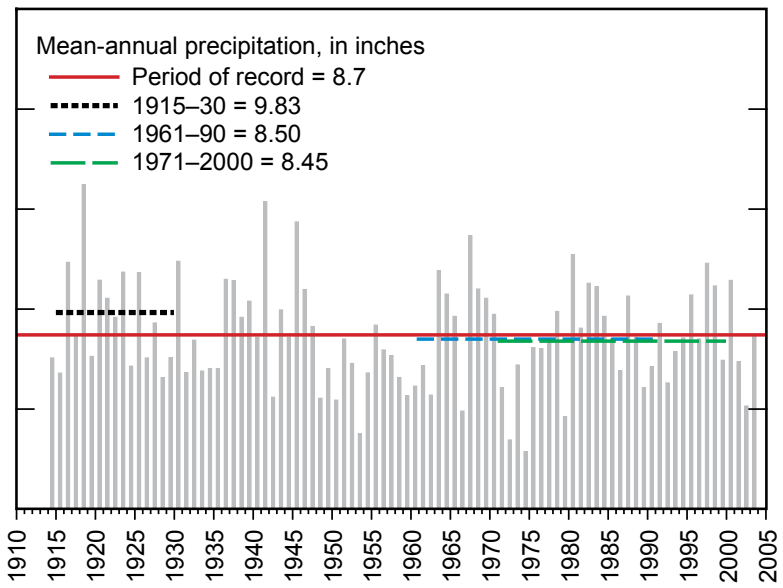

Figure 2. National Weather Service long-term annual precipitation for selected climate stations in Nevada: (A) Austin, (B) Boulder City, (C) Elko, (D) Fallon, (E) Mina, (F) McGill, (G) Lovelock, (H) Searchlight, and (I) Winnemucca. 

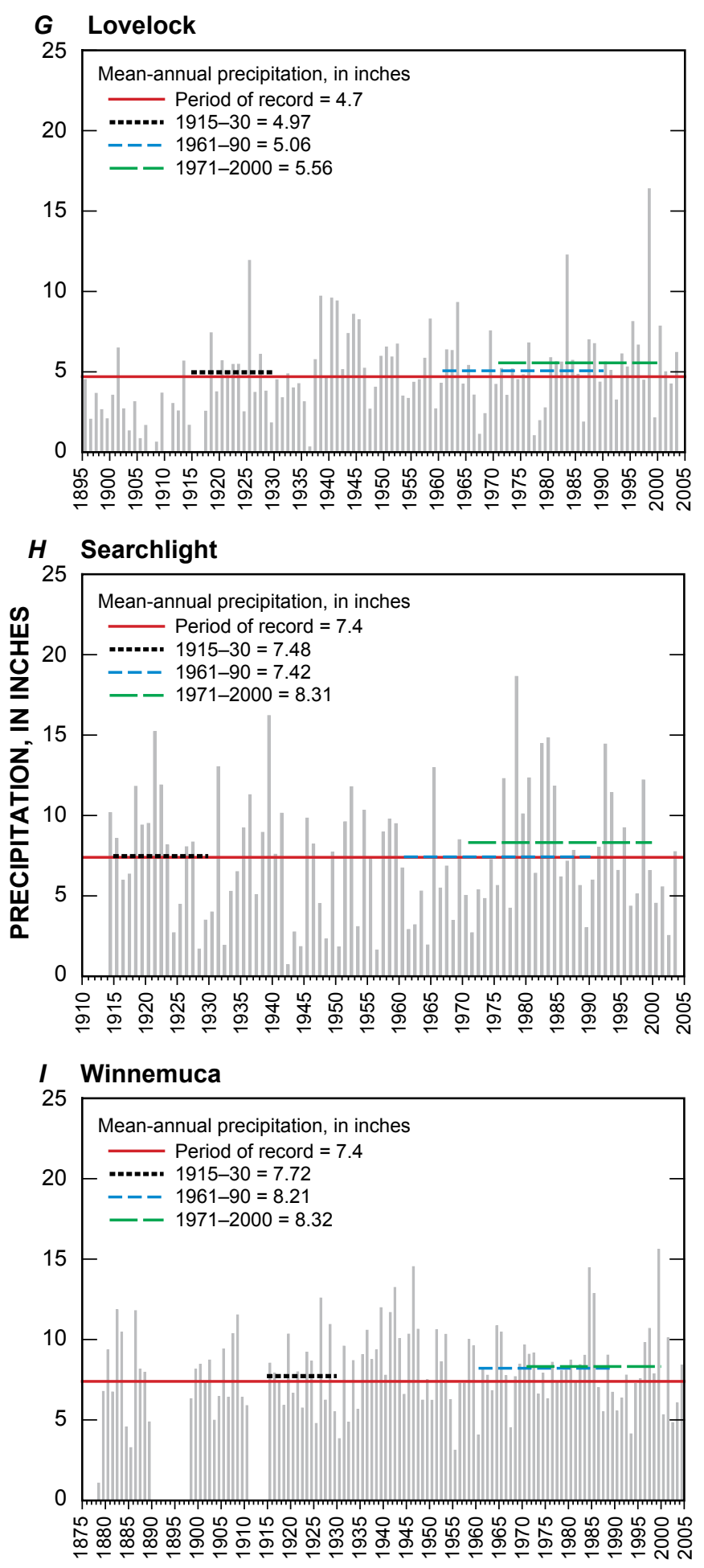

Figure 2. National Weather Service long-term annual precipitation for selected climate stations in Nevada: (a) Austin, (b) Boulder City, (c) Elko, (d) Fallon, (e) Mina, (f) McGill, (g) Lovelock, (h) Searchlight, and (i) Winnemucca-Continued. precipitation, linear climate-elevation regression equations were developed to model large-scale landscape features. Regression equations were developed from clusters of contiguous cells using a procedure known as "windowing", producing a moving average from which precipitation is predicted for every DEM cell. Differing equations accommodate the influence of various large-scale topographic orientation (or aspect) and moisture-blocking terrain features, and account for the resolution of the station precipitation data. The effect of variables other than elevation are accounted for in the regression equations by mathematically assigning precipitation data weights based on several factors, which include distance from the PRISM grid cell, elevation, cluster (the effect of several stations in an area), vertical layer (where the grid cell is above or below the inversion layer), coastal proximity, and perhaps one of the more important weighting factors, the "effective" terrain.

Station data are rarely of sufficient density and accuracy to adequately describe orographic distribution of precipitation. The effectiveness of terrain features in amplifying precipitation depends on the ability of topography to block and lift moisture-bearing air. PRISM is a regional model with a coarse DEM data set of $4 \mathrm{~km}$. To adequately model three-dimensional (3D) precipitation patterns for steeply rising features (thus capturing the appropriate orography) and conversely, not oversimulate orographic effects for gently sloping topography, the elevation of a PRISM grid cell is adjusted to a DEM data set that has been modified to accentuate the dominant terrain features (Daly, 1998). The modified grid, referred to as "an effective terrain height grid" is created by producing a smoothed "base" elevation grid which is a spatial average of minimum elevations over a specific radius $(40 \mathrm{~km})$. The base elevation grid is subtracted from the original DEM. This new elevation grid is spatially averaged resulting in a final elevation data set used to identify climatologically significant $3 \mathrm{D}$ features.

Empirically-defined thresholds are determined for the two-dimensional (2D) and 3D model operations. For grid cells whose effective terrain height meets or exceeds the 3D threshold, yielding a 3D index equal to 1, the PRISM regression function operates normally. For a 3D index less than 1 , the influence of terrain is gradually diminished and the terrain-related weights (aspect, elevation, and vertical layer) are reduced. For cells with a 3D index of zero, the climate stations are weighed by distance and clustering only, resulting in a $2 \mathrm{D}$ interpolation.

The PRISM estimates for Nevada were generated for two 30-yr periods, 1961-90 and 1971-2000. PRISM precipitation estimates are simulated output from the regression models and, as such, exhibit inherent error or uncertainty. To address the degree of uncertainty in the estimated precipitation values, the authors of the model (Daly and others, 1994) calculated 95 percent prediction intervals. This information, however, is not provided in the web-based PRISM documentation for the Nevada map; therefore, error data are not available to evaluate differences between the predicted values and the recorded values. 


\section{Methods for Comparing the PRISM Model to Recorded Data}

PRISM estimates for both of the Nevada PRISM maps (Oregon Climate Service, 2004b) were based on precipitation data from 209 sites (referred to as "control points") across the State (Christopher Daly, Oregon State University, written communication, 2002). Figure 1 shows the location of the 209 PRISM control points and 164 sites where long-term precipitation data were collected. Information about the control points (for example, station name, period of record used, whether a control point is a measured site or an estimated value) is proprietary information and precipitation values associated with these sites were not published. Seventy-eight percent of the 209 control sites correspond to known stations with recorded precipitation (fig.1). These include 67 National Weather Service (NWS) sites with a computed 30-yr precipitation average; 26 Natural Resources Conservation Service SNOTEL monitoring sites (SNOTEL records typically began in the 1980s); and 71 other NWS Coop sites archived at the Western Regional Climate Center (WRCC), hereafter referred to as WRCC sites (appendix 1). The remaining 45 sites, 22 percent of the total control points, do not correspond to known climate stations. These stations are assumed to be in the category of data referred to in the PRISM documentation (Oregon Climate Service, 2004b) as "pseudo-stations". Pseudo-stations are climate stations with 30-yr estimates determined using information other than daily measured precipitation. Some of these estimates may represent mean annual estimates from storage gages where precipitation measurements represent an accumulation of precipitation over time rather than hourly or daily or estimates provided by the Nevada State Climatologist (George Taylor, Oregon State Climate Service, oral commun., June, 2005). Figure 1 also indicates that a number of WRCC sites (about 23 percent of the total) do not correspond to any of the control points, and were assumed to have been omitted from the control data set for unknown reasons. Several points appear to be mismatched, suggesting error in the PRISM control point location attribution. There are several SNOTEL sites outside the State boundary in northwestern Nevada that were not a part of this study's analyses that may have been used in the development of the PRISM estimates.

It was not possible to evaluate the accuracy of PRISM estimates in areas where climate stations do not exist, or to evaluate the accuracy of the "pseudo-stations". Understanding the source and period of record of the PRISM precipitation data is essential in determining whether comparisons made with recorded data are realistic. The $30-y r$ averages for the 164 precipitation locations listed in table 1 were used in the comparative analyses described in this report. To minimize the uncertainty associated with comparing the PRISM estimates to data from stations with varying periods of records, often with records shorter the PRISM 30-yr period, the station data were evaluated as three separate data sets in order of decreasing correspondence to the two 30-yr periods; the "National Weather Service normals" (hereafter referred to as the NWS normals); the WRCC average; and the 1971-2000 SNOTEL averages, obtained from the Natural Resources Conservation Service (NRCS; 2005). The term "recorded" rather than "observed" or "measured" will be used when referring to climate station data to emphasize that the 30 -yr averages often represent estimated values, rather than a mathematical average of measured precipitation events.

\section{Climate Station Averages}

Climate station averages for both the NWS normals and the WRCC averages for the 1961-90 and 1971-2000 periods were obtained from the Western Regional Climate Center (Western Regional Climate Center, 2004) and compiled in appendix 2. Due to the differences in how the 30-yr averages were computed, precipitation values for the NWS normals and the WRCC 30-yr averages will sometimes differ for the same period. The NWS normals, however, are considered to be the

Table 1. Summary statistics of percent difference between the PRISM precipitation data and the recorded data sets for the 1961-90 and 1971-2000 periods

\begin{tabular}{|c|c|c|c|c|c|c|c|c|c|}
\hline $\begin{array}{c}\text { Data sets } \\
\left.\text { (percent difference }{ }^{1}\right)\end{array}$ & Number $^{2}$ & Mean & Median $^{3}$ & $75 t^{4}$ & 25 th $^{5}$ & IOR $^{6}$ & Maximum & Minimum & Range $^{7}$ \\
\hline (PRISM 1961-90) - (NWS 1961-90) & 67 & 1.48 & -0.6 & 5.11 & -3.38 & 8.49 & 54.8 & -16.3 & 71.2 \\
\hline (PRISM 1971-2000) - (NWS 1971-2000) & 92 & 3.01 & 0.91 & 6.09 & -4.72 & 10.8 & 59.1 & -33.7 & 92.8 \\
\hline (PRISM 1971-2000) - (WRCC 1971-2000) & 131 & 0.26 & -3.1 & 5.6 & -8.93 & 14.5 & 115.0 & -55.6 & 171 \\
\hline \multicolumn{10}{|c|}{${ }^{1}(($ PRISM - recorded data)/recorded data) x 100 (see comment on pg. 8) } \\
\hline \multicolumn{10}{|l|}{${ }^{2}$ Number of climate sites in data set. } \\
\hline \multicolumn{10}{|c|}{${ }^{3}$ Percent difference value numerically in the middle of the data set. } \\
\hline \multicolumn{10}{|l|}{${ }^{4}$ Percent difference value in the 75 th percentile. } \\
\hline \multicolumn{10}{|l|}{${ }^{5}$ Percent difference value in the 25 th percentile. } \\
\hline \multicolumn{10}{|c|}{${ }^{6}($ Interquartile Range $)=$ Absolute difference between the 75 th quartile and the 25 th quartile. } \\
\hline
\end{tabular}


most accurate reporting of the 30 -yr mean. The NWS normal represents the arithmetic mean of a climatological element computed over three consecutive decades (World Meteorological Organization, 1989), following a consistent methodology to produce a time series that best represents the measured data (National Weather Service, 2002). The 30-yr average reported by WRCC (computed for 138 of the 164 known sites) is the summation of the mean monthly values computed from the mean daily values for the existing period of record, which may or may be coincident with either of the 30 -yr periods discussed in this report. For example, 35 percent of the 138 WRCC sites (fig.1) have periods of record less than either of the 30-yr periods. Few of the climate stations represented in either the NWS or the WRCC data set are at elevations exceeding 7,000 $\mathrm{ft}$; therefore, the 26 SNOTEL sites located in Nevada and their respective long-term averages were included in some of the analyses. The SNOTEL data collection network measures precipitation, air temperature, and snow water equivalence (SWE) at high-elevation sites for several river basins in Nevada. The NWS Cooperative network is regarded nationally as the most definitive source of information on United States climate trends for temperature and precipitation (National Weather Service, 2005). There are, however, no accuracy ratings associated with this data, making comparisons with other data (such as PRISM data) problematic.

The four data sets were subjected to statistical tests to determine whether there were significant differences between the means of the recorded data sets. Results from the parametric t-test indicate that there is no significant difference between the two 30-yr NWS normals data sets nor between the 1961-90 NWS normal and the 1961-90 WRCC average, hence these three data sets are considered interchangeable. There are, however, statistically significant differences for certain combinations of the recorded data sets. Specifically, the WRCC 1971-2000 average is greater than both the NWS 1971-2000 and the WRCC 1961-90 average.

\section{PRISM and Climate Station Averages}

The PRISM precipitation data and the associated DEM data were obtained for the two 30-yr periods (1961-90 and 1971-2000; Oregon Climate Service, 2004b). The data are digital, raster (grid cell) data at a resolution of $4 \mathrm{~km}$ for the State of Nevada, and represent mean annual average precipitation for each 30-yr period. A digital data set of the point observations and their respective mean annual precipitation values were combined with the PRISM data using a geographic information system (GIS), and analyzed with statistical programs. Appendix 2 lists the 30-yr precipitation estimates for each of the 164 climate stations and the source of the data. The two 30-yr recorded data sets and the PRISM grid values were compared and relative percent differences [((PRISM - recorded data)/recorded data) $\times 100$ ], hereafter known as percent difference, and absolute differences (PRISM minus recorded data) were computed, and basic summary statistics generated.
Scatter plots of the percent and absolute differences, latitude, longitude, recorded station elevation, and PRISM DEM elevation were examined to determine trends.

The Inverse Distance Weighed (IDW) technique (Philip and Watson, 1982) was used to generate statewide maps delineating areas of equal precipitation differences relative to the recorded data. The areas between the recorded data points and the associated percent differences are not to be used as estimates for precipitation differences between PRISM and 'true' precipitation in areas where measured data are absent. Rather, the IDW maps are simply a means of representing spatially the differences for specific data points across the State with interpolated differences between the known data points. IDW interpolation determines grid-cell values using a linearly-weighted combination of a set of sample points. The surface being generated is that of a locationally dependent variable - in this case, the percent difference for each station point. The weight is a power function of the inverse distance, or 1/distance. A higher exponent, or weight, allows the area surrounding the data points to exhibit more influence (thus creating a surface with more detail around the data points). Conversely, specifying a lower exponent influences surrounding areas further away, and the resultant product is a surface with less detail. The current study used a weight of 2 , which represents an average weight.

\section{Station Elevations and PRISM Digital Elevation Model Elevation Grid Values}

PRISM elevations using 4-km grid cells were compared to the 30-m USGS National Elevation Data (NED) to provide additional verification of the PRISM and station elevations. Site elevation is a critical component of the PRISM regression-based methodology. The NED data was projected to match the PRISM data coordinate system, aggregated to match the PRISM cell boundaries, and a mean areal elevation was computed to match each PRISM cell. Differences between the climate station elevations, PRISM DEM elevations, and the NED elevations are presented in appendix 3.

\section{PRISM and Hardman Precipitation Estimates by Hydrographic Areas}

The Hardman precipitation map of Nevada represents a smooth surface defined with lines of equal precipitation developed from weather records and other data collected from 1915 to 1930. Precipitation zones in Hardman's map are defined at large, irregular intervals (for example, less than 5 in., 8 in., 12 in., 15 in., and 20 in.). Areas generally above 9,000 ft were referenced by Hardman as simply "greater than 20 in." (Eakin and others, 1965). This was attributed to a lack of highelevation climate stations in this early period of record. The 1915-30 period was characterized by normal or below-normal precipitation, illustrated in the long-term station data in figure 
2, while the 1961-90 and 1971-2000 periods were near-normal or wetter-than-normal periods (Dettinger and Schaefer, 1995, p. 195)

Several USGS studies used the Hardman precipitation estimates (Harrill and Monroe, 1970, Harrill, 1973; Rush and Kazmi, 1965; Glancy, 1968; VanDenburgh and Rush, 1974) for the early, reconnaissance studies. More recently, the PRISM data has been used (Berger, 2000a; Berger, 2000b; Nichols, 2000). Reliable estimates of precipitation for a particular station are difficult to derive from the Hardman precipitation map. However, using a digital data set of Hardman precipitation zones, mean precipitation volumes were computed and comparisons were made between the Hardman precipitation zones and both PRISM 30-yr periods, for each of the 232 hydrographic areas ${ }^{1}$ (HAs) in Nevada. The resultant data sets were evaluated with statistical tests and percent differences computed. Areas labeled as 'greater than 20 in.' in the Hardman map were set to $20 \mathrm{in}$. This results in an inherent under-estimation of precipitation volumes for those HAs with significant area above roughly $9,000 \mathrm{ft}$.

\section{Results}

Comparisons were made between the PRISM 1961-90 and the PRISM 1971-2000 data sets and the corresponding NWS and WRCC data sets. Results for each 30-yr period are presented separately in the following sections. For purpose of this report, the authors arbitrarily selected 15 percent as an "acceptable" level of error or difference. This is comparable to the USGS surface-water record rating of "fair" (Stockton and others, 2003). Basic statistics were computed for the four pairs of data (the PRISM data set for each 30-yr period paired to each of the two recorded data sets) to determine their statistical distributions. Box plots were used to compare and contrast the distribution of percent and absolute differences between PRISM and the recorded data sets (fig. 3). The whiskers drawn above and below the box represent the $90^{\text {th }}$ and $10^{\text {th }}$ percentiles. Values beyond the whiskers in either direction are plotted individually and are defined as "outside values" (Helsel and Hirsch, 1992).

All of the pairs of data are non-normally distributed (normality assumes a bell-shaped curve where almost all the measurements will be within 3 standard deviations of the mean). All data sets have mean absolute and relative percent differences equal to zero, as determined with non-parametric statistical tests. In general, the distributions of percent differences (fig. 3 and appendix 1) between the PRISM grid values and the NWS $30-y r$ precipitation averages have the narrowest interquartile ranges (the differences between the $25^{\text {th }}$ and $75^{\text {th }}$ percentiles) and the narrowest overall ranges (the differences between the maximum and minimum values). The differences between the WRCC average and the PRISM grid values have the broadest interquartile ranges and the broadest overall ranges in percent differences.

Differences between the three elevation data sets are listed in appendix 3 relative to the station elevation data. With a few exceptions, there is good agreement between the PRISM DEM and the 30-meter data set, and t-tests indicate no statistical difference between the two digital elevation data sets. Differences exist, however, between the reported station elevation and both DEM data sets. Most notably, these locations correspond to stations with large differences between estimated and recorded precipitation. The percent differences between PRISM and the recorded data sets for both $30-y r$ periods are listed in appendix 4 by station identifier and name.

\section{1-90 Comparisons}

The relation between the recorded data sets and percent difference and absolute difference between the recorded data sets for 1961-90 and the PRISM estimated precipitation is shown in figure 4 . The absolute difference plots have been included to provide a sense of the magnitude of the difference relative to inches of precipitation. Differences relative to latitude and longitude also were examined but for the most part shown little, if any, trend. Comparing the differences to the NWS normals (fig. 4A), the largest percent differences are at Tuscarora (55 percent) and at Smokey Valley (-16 percent), though overall the scatter does not indicate a trend. The largest percent difference for the WRCC data set (fig. 4A) is at Indian Springs ( $>100$ percent), and nine sites have percent differences greater than 50 percent. The largest absolute differences (fig. 4B) for the WRCC data set are +11.5 in. at the Stateline-Harrah station and -6.7 in. at the Red Rock Canyon site. Again the scatter does not show a trend. As discussed earlier, the large differences for these and other sites in the WRCC data set are attributed, in part, to the period of record used to compute the 30-yr average. The absolute differences for the NWS data set (fig. 4B) suggest PRISM is within an inch for most of the points. Exceptions are the Tuscarora and the Ruby Lake sites, where absolute differences are +6.7 in. and +3.7 in. respectively.

The relation between station elevation and percent and absolute differences between the recorded precipitation data sets and PRISM estimates (fig. 5) show that the largest deviations occur when the station elevation is about $6,000 \mathrm{ft}$. Similarly, the PRISM DEM (not shown) has the largest deviations between 5,500 and about 8,000 ft. For the WRCC data (fig. $5 \mathrm{~A}$ ), the percent differences indicate the largest spread of data is between 4,000 and 7,500 ft in elevation. Plots of absolute differences for the recorded data points (fig. 5B) indicate that

\footnotetext{
${ }^{1}$ Formal hydrographic areas in Nevada were delineated systematically by the USGS and the Nevada Division of Water Resources in the late 1960s for scientific and administrative purposes (Rush, 1968; and Cardinalli and others, 1968). The official hydrographic-area names, numbers, and geographic boundaries continue to be used in USGS scientific reports and Division of Water Resources administrative activities.
} 


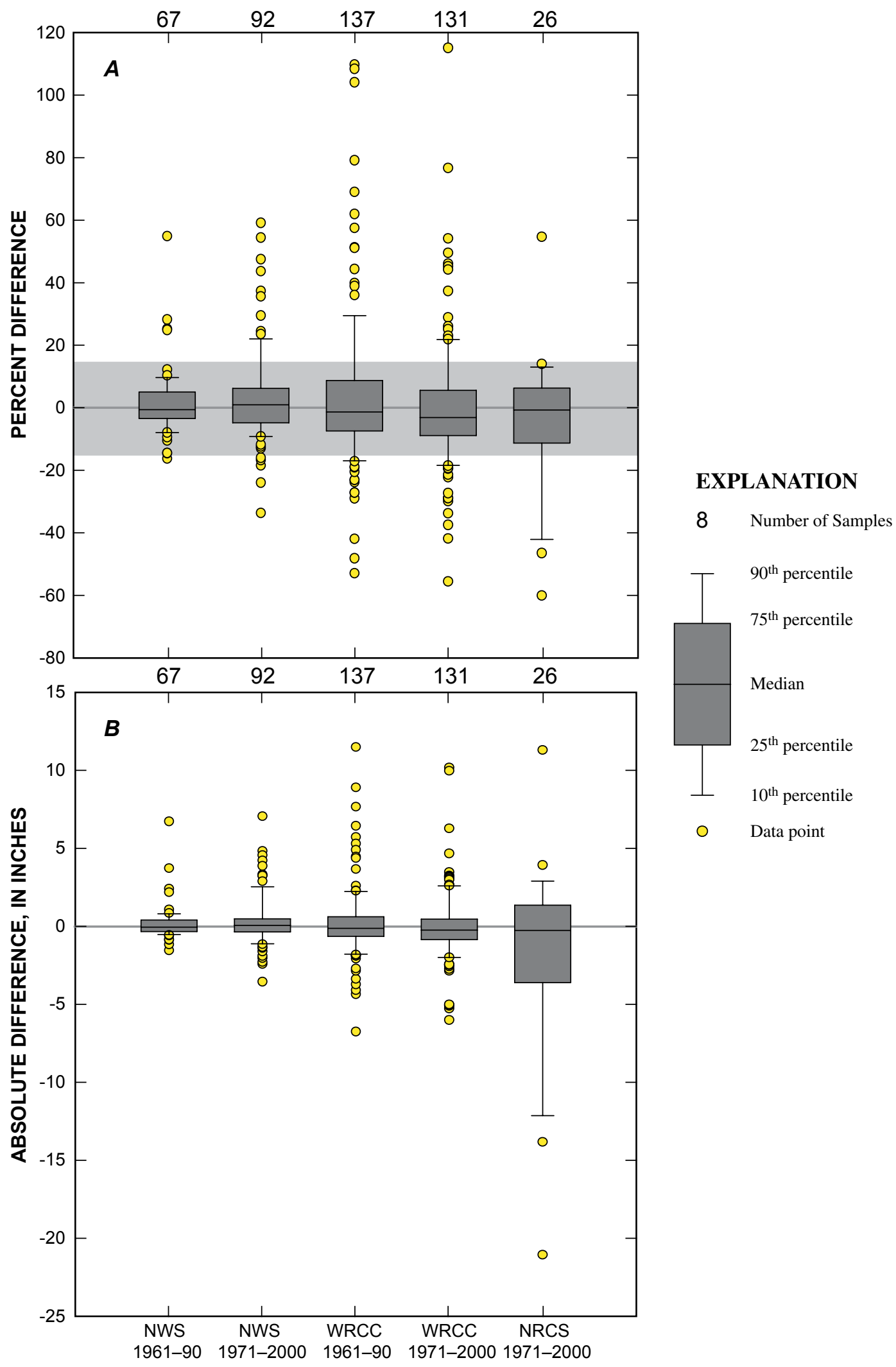

Figure 3. Percent difference and absolute differences between PRISM estimated precipitation and National Weather Service and Western Regional Climate Center recorded data for 1961-90 and 1971-2000 periods. Shaded area represents $\mathrm{PRISM}$ estimates within \pm 15 percent of the recorded data. 

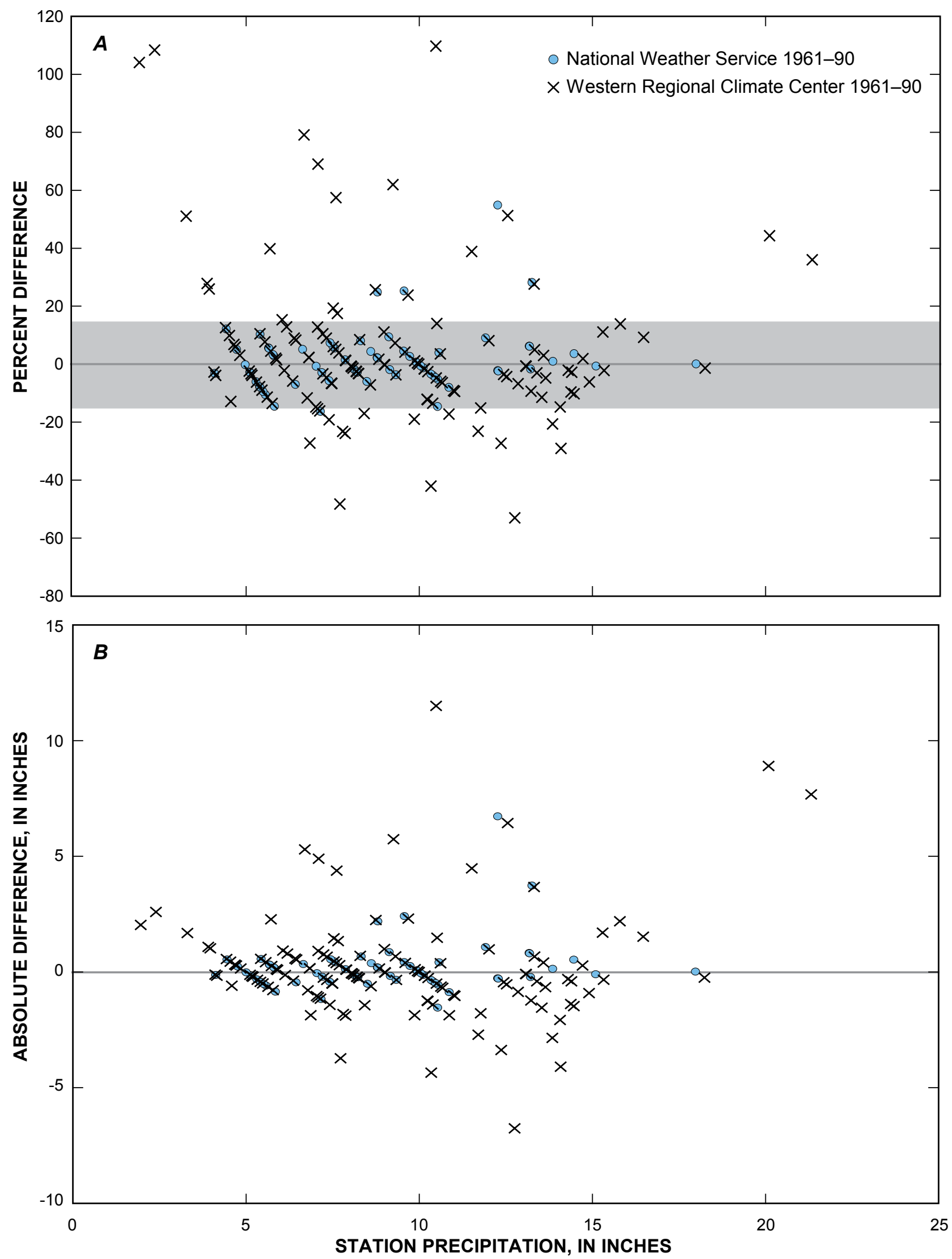

Figure 4. Scatter plot of relation between recorded precipitation for National Weather Service and Western Regional Climate Center sites and percent difference (A) and absolute difference (B) between PRISM estimated precipitation and the recorded precipitation for the 1961-90 period. Shaded area represents PRISM estimates within \pm 15 percent of the recorded data. 

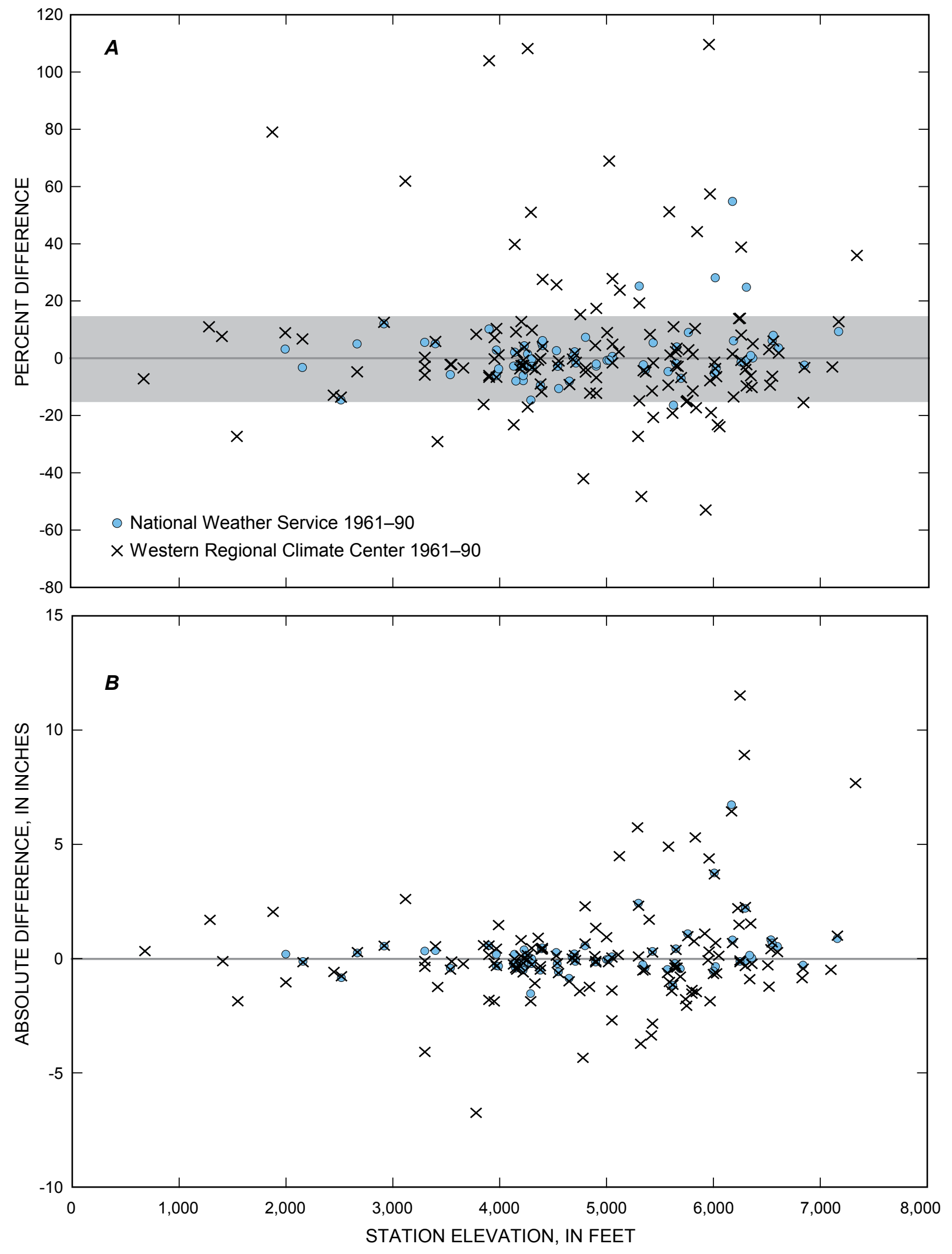

Figure 5. Scatter plot of relation between actual station elevation and percent difference (A) and absolute difference (B) between PRISM estimated precipitation and the recorded precipitation for the 1961-90 period. Shaded area represents PRISM estimates within \pm 15 percent of the recorded data. 
the largest differences are between 5,000 to $8,000 \mathrm{ft}$ elevations for the WRCC points and between 5,000-6,000 ft for the NWS data set.

A comparison of the percent difference and the PRISM precipitation estimate suggests that, in general, overestimation increases with the magnitude of the PRISM estimate. Exceptions are the North Las Vegas and the Indian Springs sites, where the PRISM estimates (4 and 5 in., respectively) exceed the recorded values by over 100 percent.

A contour map of percent difference between the PRISM estimates and the NWS data (fig. 6) shows that the PRISM estimates are within 5 percent of the NWS data in most of the State. Percent differences greater than 15 percent coincide with the Tuscarora, Sunnyside, Ruby Lake and McGill sites (appendix 4). Areas where PRISM precipitation estimates are 15 percent or more greater than the station normals are at the Smokey Valley, Orovada 4 WSW, and Boulder City sites. For the WRCC data set (fig. 7), most of the State is within the -15 percent to +15 percent range, though several anomalous areas are present. At two sites in southeastern Nevada (Indian Springs and North Las Vegas), PRISM overestimates precipitation by more than 50 percent. In central, northeastern, and western Nevada there are several sites (Tuscarora, Jackpot, Oasis, and Ruby Lake) where precipitation is overestimated by more than 30 percent. At several sites located throughout the State, PRISM underestimates the recorded precipitation by more than 15 percent, specifically the Red Rock Canyon, Blue Eagle Ranch, Blue Jay Highway, and Gerlach sites.

\section{1-2000 Comparisons}

The relation between the recorded data sets and percent and absolute differences between the recorded data sets for 1971-2000 and the PRISM estimated precipitation is shown in figure 8. The NWS 1971-2000 data set included 23 more stations than for the previous period; however, statistical tests for location and normality are similar to the 1961-90 period. The largest positive percent difference is again at Tuscarora (59 percent) and the largest negative difference is at Red Rock Canyon (-34 percent). Compared to the 1961-90 period, the NWS data (fig. 3A) has more stations with a negative percent difference (where PRISM underestimates precipitation at those sites relative to the recorded station data), whereas the distribution of the WRCC data is similar to the earlier period. This is partly due to the WRCC data set having station records that overlap both 30 -yr periods. The largest percent difference for the WRCC data set is at Sand Pass (115 percent), three other estimates are more than 50 percent greater than the WRCC average. The largest negative difference is 56 percent at the Blue Jay Highway site. Figure 8 includes data from the high-elevation SNOTEL sites. The percent difference for the SNOTEL high-elevation sites was calculated using the 19712000 average reported by the Natural Resources Conservation Service (2005). In general, PRISM estimates at SNOTEL sites are within 15 percent of the reported value, although at most sites PRISM underestimates SNOTEL precipitation (fig. 3 ). Six sites exceed \pm 15 percent difference, with the largest differences in northeastern Nevada at the Hole-in-Mountain (-60 percent) and Diamond Peak (+55 percent) sites. The general pattern is for PRISM to underestimate precipitation at sites with mean annual precipitation greater than $25 \mathrm{in}$. The data suggest that, in general, the absolute differences for the WRCC and NWS sites increases for sites with more than 10 in. of recorded precipitation (fig. 8B).

Plots of differences versus latitude (not shown) for the NWS and the WRCC data suggest that there is a slight trend towards increasing in difference from south to north; however, it is not statistically significant. The relation between station elevation and percent and absolute differences is shown in figure 9. Both the NWS and WRCC data sets show that the largest differences are in the 6,000 to $7,000 \mathrm{ft}$ range, which is consistent with the distribution of PRISM DEM elevation errors (data not shown). A comparison of the PRISM precipitation estimates and the NWS and WRCC recorded data (data not shown) suggests a tendency for PRISM to overestimate with increasing precipitation.

A contour map of the percent differences for the 19712000 period (fig. 10) indicates that the PRISM data estimates of precipitation are within 15 percent of the NWS data in most of the State. As in previous figures, the areas between the known climate stations are interpolated and cannot be interpreted literally. The anomalous areas in figure 10 are similar in locations to those in figure 6 . The map generated for the WRCC sites (fig. 11) includes the 26 SNOTEL sites (red sites). In general, PRISM estimates the SNOTEL 30-yr average within \pm 15 percent, with the exception of the following sites, two in eastern Nevada (Ward Mountain and Holein-Mountain), two in central Nevada (Diamond Peak and Big Creek Summit), and one in northern Nevada (Lamance Creek), and one in western Nevada (Mt. Rose Ski Area).

\section{Comparison of Hardman and PRISM Precipitation Estimates by Hydrographic Area}

Volume of precipitation for the 232 HAs in Nevada is listed in appendix 5. Absolute and percent differences were computed between estimates of the volume of precipitation from the Hardman (1965) map and from the PRISM data sets for the two 30-yr periods (Appendix 6). In general, the percent differences are similar for both periods. Statistical tests show high correlation between the two PRISM data sets and a significant difference between the Hardman and PRISM volume estimates for the two 30-yr periods. Estimates based on the Hardman map average about 1.5 in. less than the PRISM estimates, with a range of about $6 \mathrm{in}$. above to about $20 \mathrm{in}$. below PRISM.

In the middle part of the State (fig. 12), PRISM estimates are less than the Hardman estimates by as much as 37 percent in some HAs. For HAs in the northeastern region, and some HAs in the southeastern region, PRISM estimates are within 


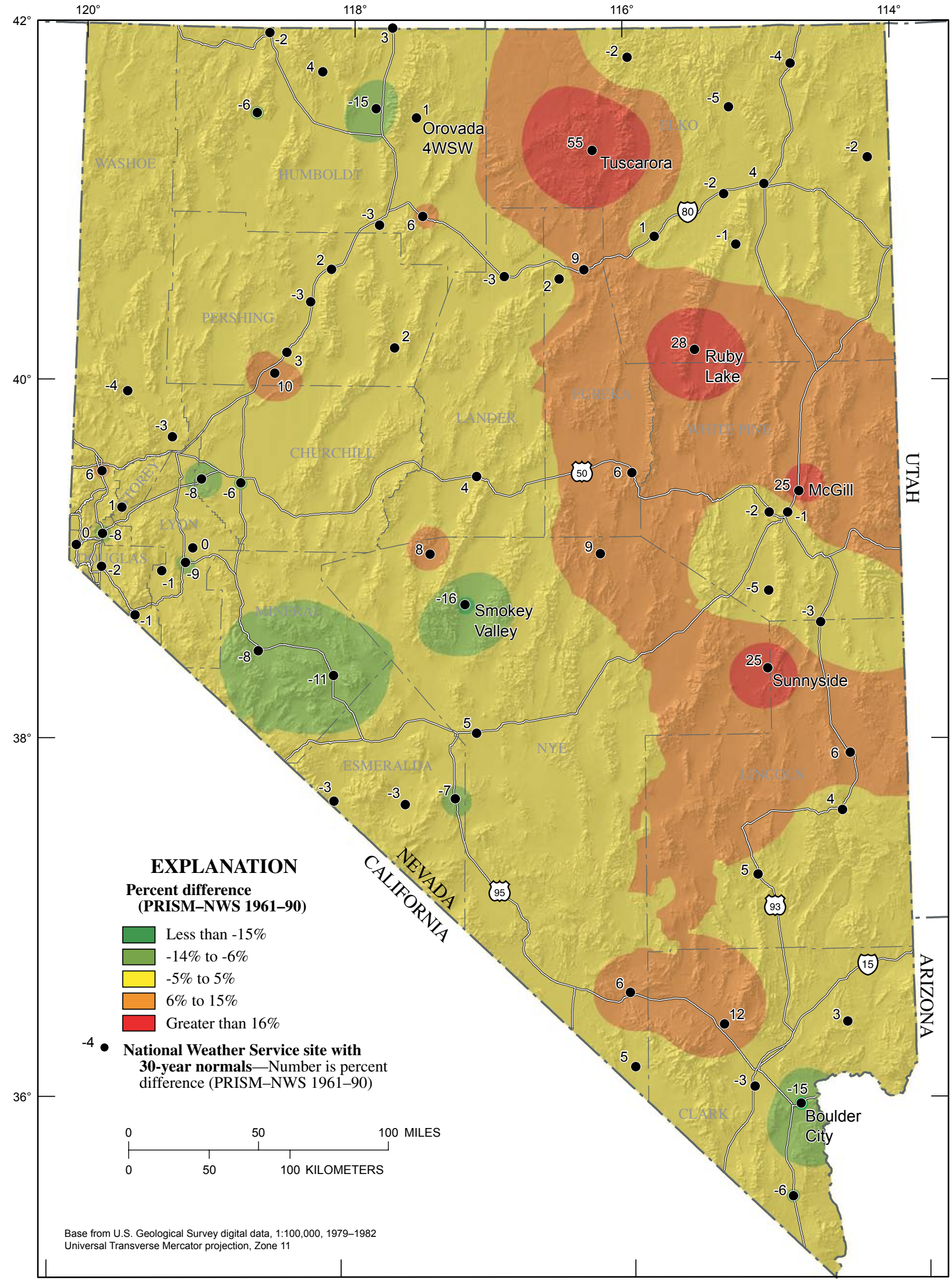

Figure 6. Percent difference between estimated PRISM precipitation values and National Weather Service recorded data for the 1961-90 period. 


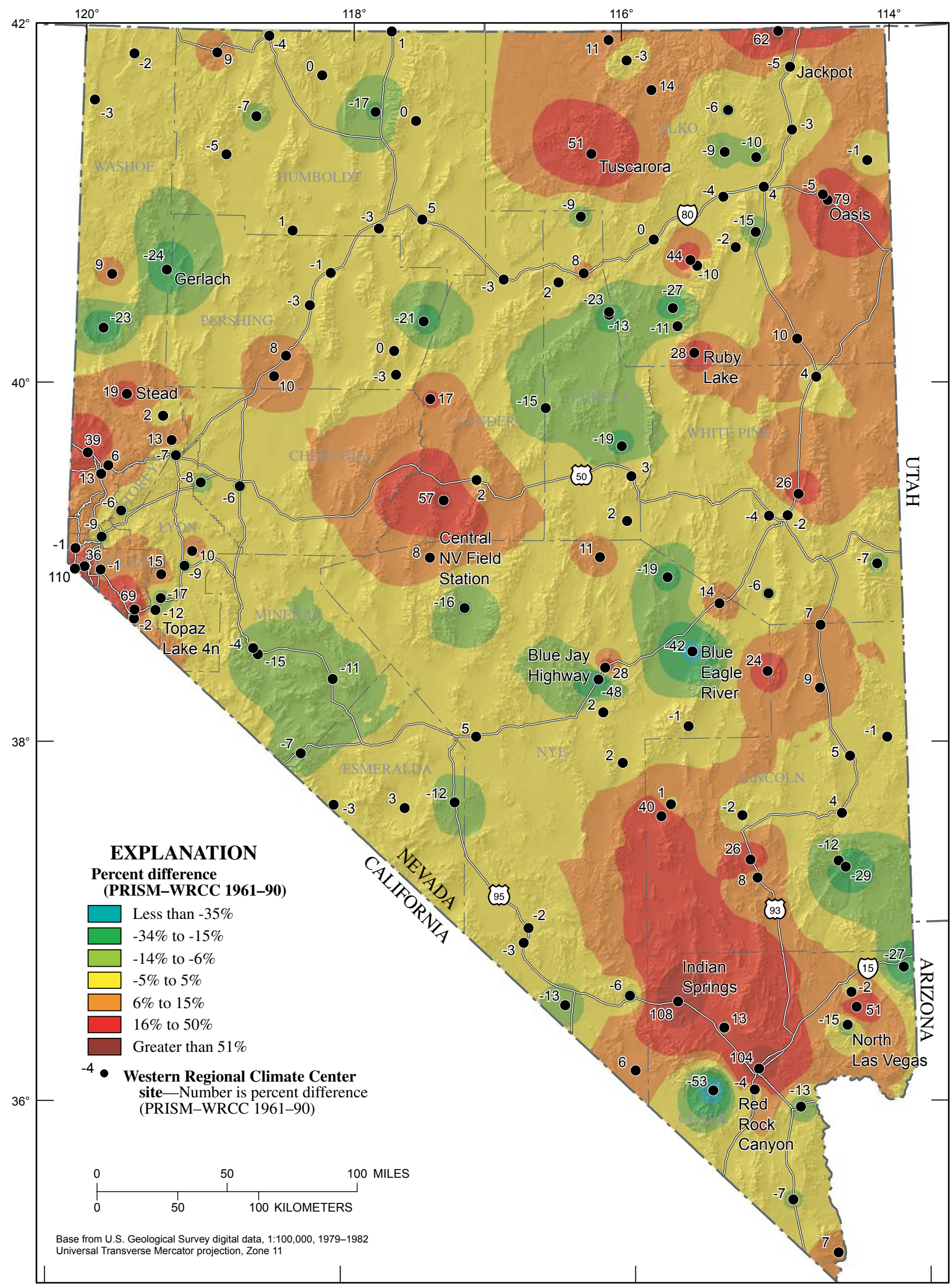

Figure 7. Percent difference between estimated PRISM precipitation values and the Western Regional Climate Center recorded data for the 1961-90 period. 

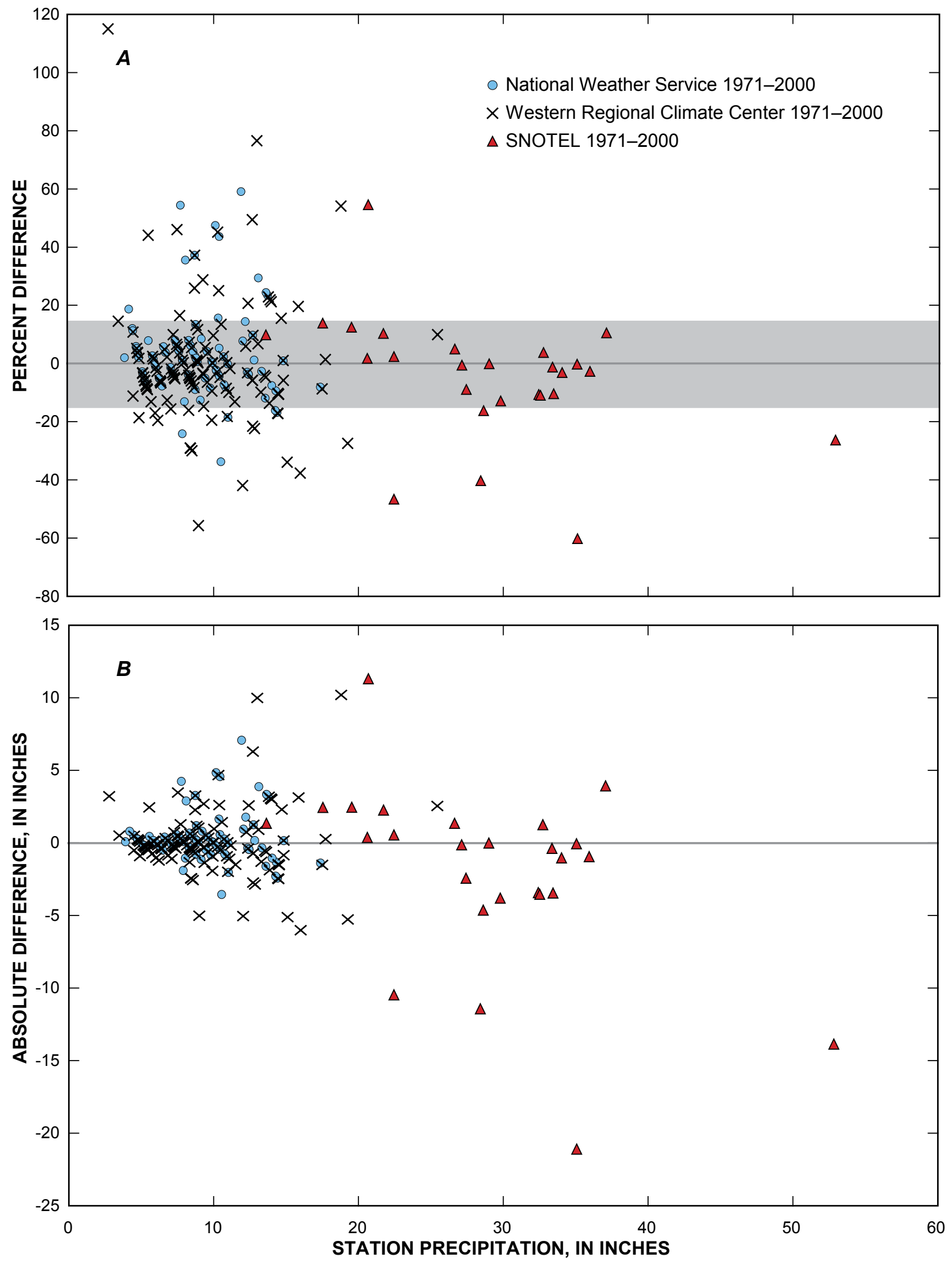

Figure 8. Scatter plot of relation between recorded precipitation for National Weather Service, Western Regional Climate Center, and SNOTEL monitoring sites and percent difference (A) and absolute difference (B) between PRISM estimated precipitation and the recorded precipitation for the 1971-2000 period. Shaded area represents PRISM estimates within \pm 15 percent of the recorded data. 

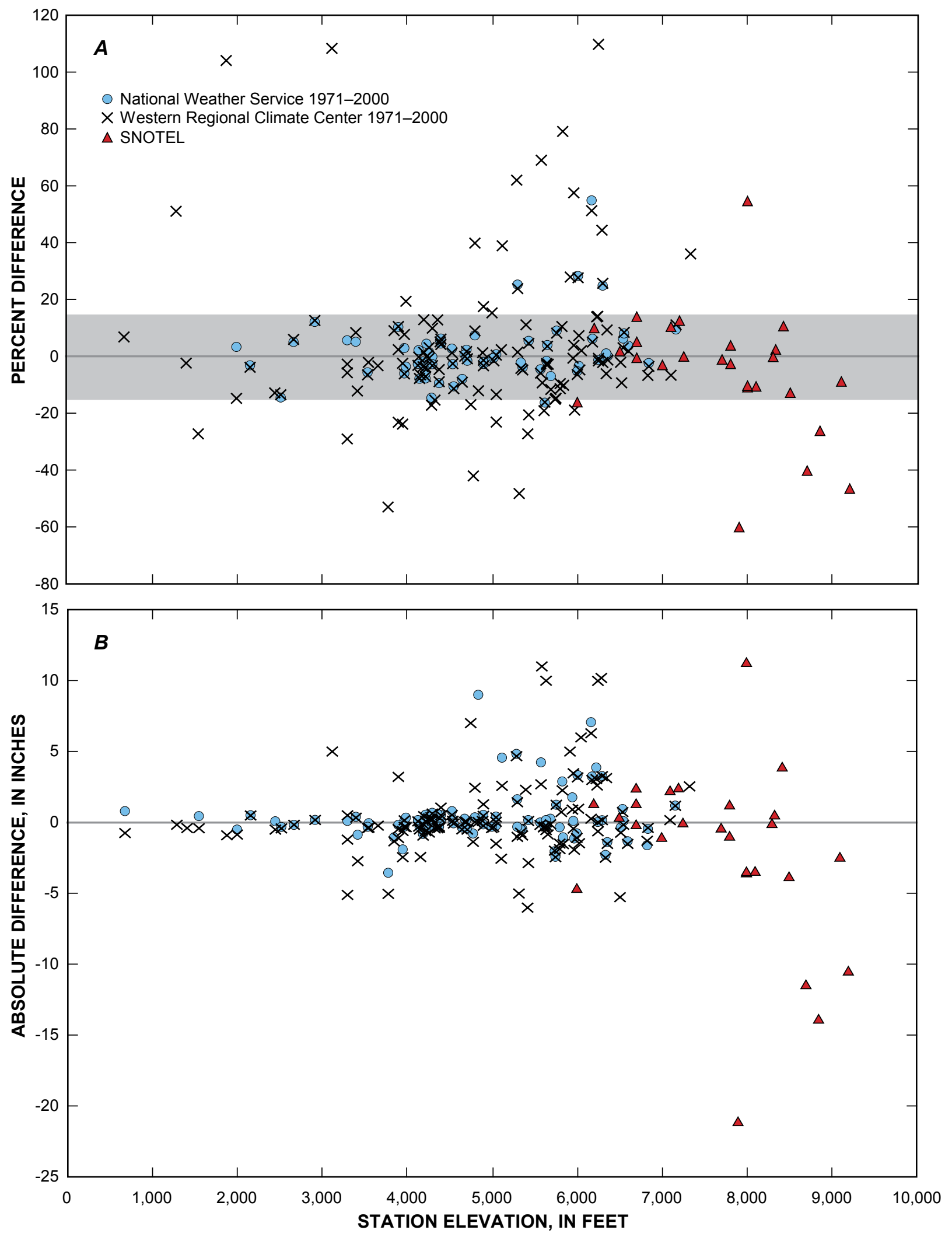

Figure 9. Scatter plot of relation between actual station elevation and percent difference (A) and absolute difference (B) between PRISM estimated precipitation and the recorded precipitation for National Weather Service, Western Regional Climate Center, and SNOTEL monitoring sites for the 1971-2000 period. Shaded area represents PRISM estimates within \pm 15 percent of the recorded data. 


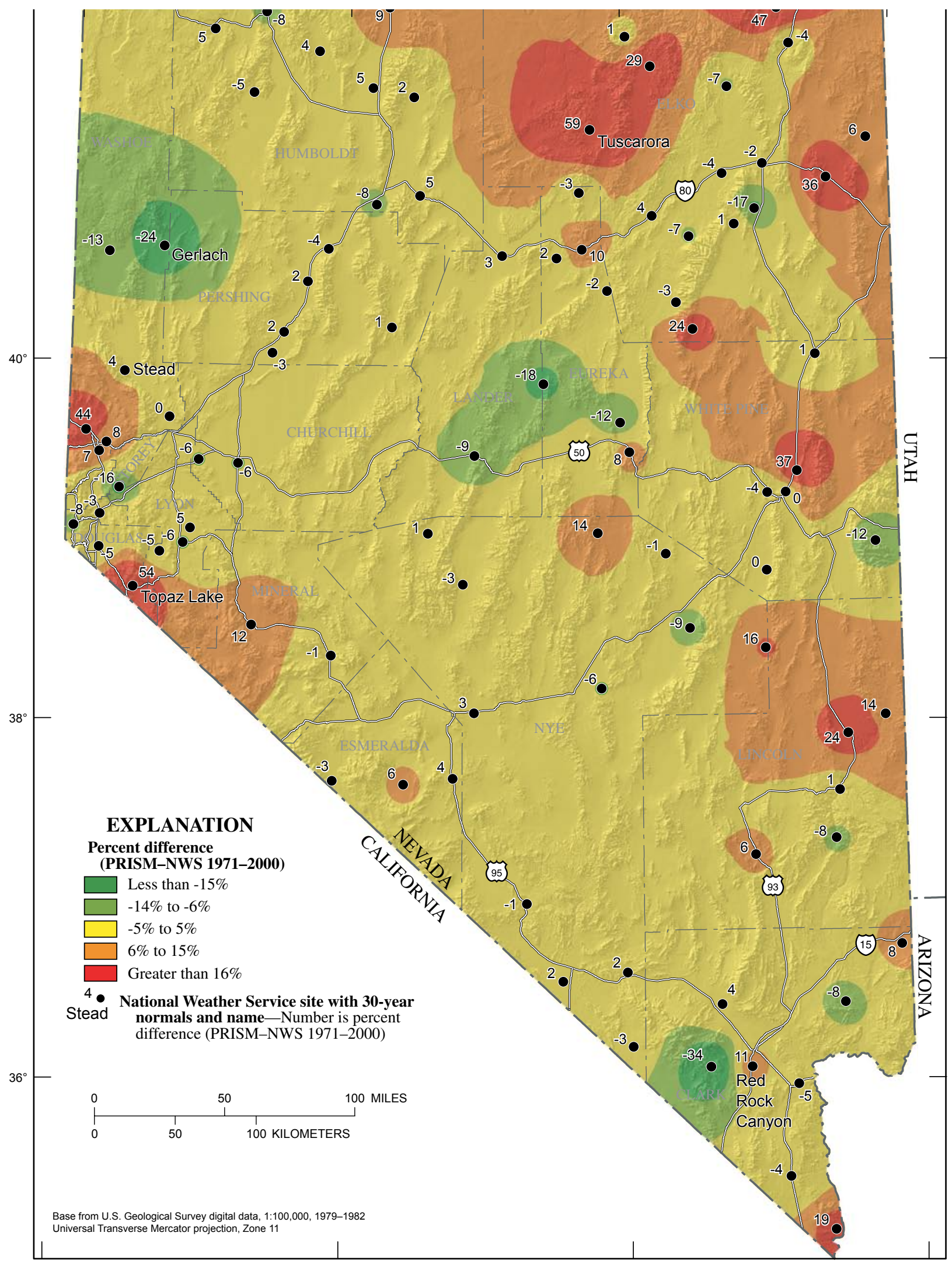

Figure 10. Percent difference between estimated PRISM precipitation values and National Weather Service recorded data for the 1971-2000 period. 


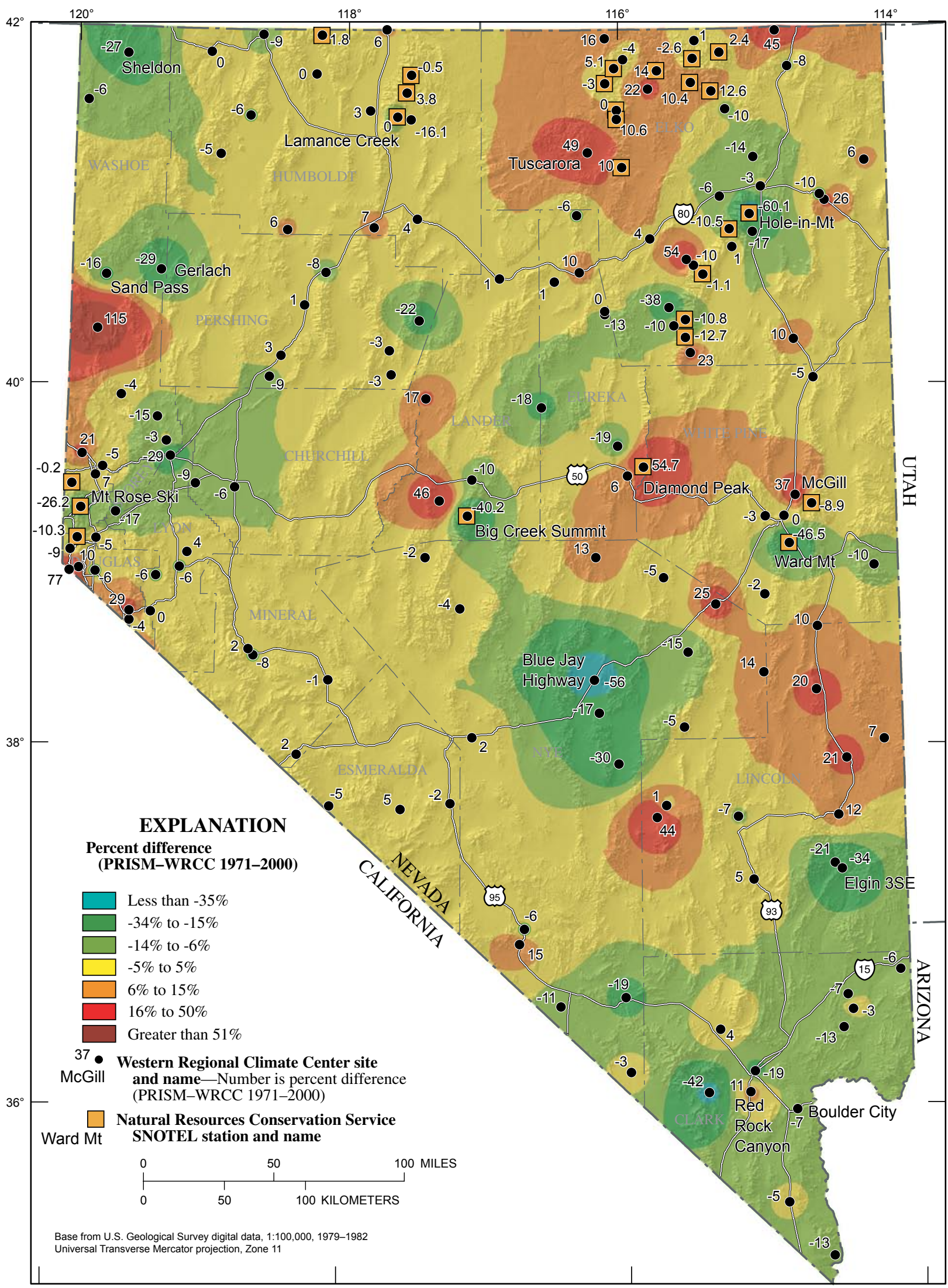

Figure 11. Percent difference between estimated PRISM precipitation values and the Western Regional Climate Center and Natural Resources Conservation Service SNOTEL recorded data for the 1971-2000 period. 


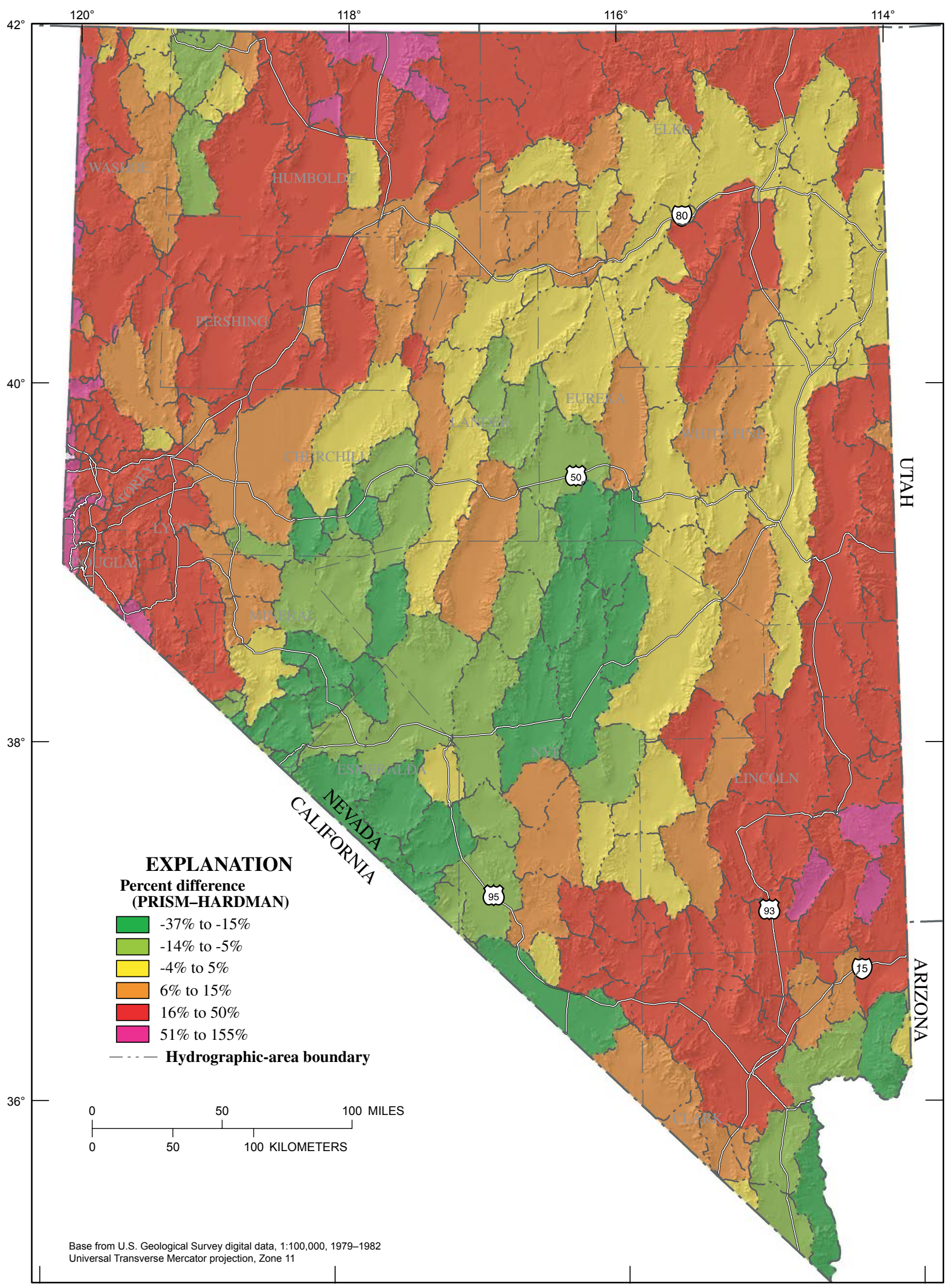

Figure 12. Percent difference between estimates of average annual precipitation in hydrographic areas using PRISM precipitation values and Hardman estimates for the 1961-90 period. 
5 percent of the Hardman estimates. Mean annual precipitation for these HAs typically range from 6 to 13 in. For much of the State outside the central region, PRISM estimates are from 6 to 155 percent more than Hardman estimates. Many of the HAs in this area have annual precipitation greater than $15 \mathrm{in} / \mathrm{yr}$. Regression plots (fig. 13) indicate the trend for more precipitation using the PRISM data, and a low coefficient of determination $\left(\mathrm{R}^{2}\right)$ to the Hardman estimate (50 percent correlation for both periods).

\section{Discussion of Results}

For the 1961-90 and 1971-2000 periods, absolute differences between PRISM and NWS precipitation estimates are on average less than one inch for most of the State, whereas the range between PRISM and WRCC estimates is from -3 in. to +3 in., with a few points exceeding $10 \mathrm{in}$. For areas that receive less than $8 \mathrm{in} / \mathrm{yr}$, this difference is significant. Much of the difference between recorded and estimated precipitation likely is the result of problems in the estimated station elevation. Seventy-eight percent of the NWS and WRCC climate stations are located in the 4,000-6,500 ft elevation zone, often on the leeward side of the mountain ranges, whereas only three stations in the data set are above 7,000 ft. Absolute differences between the PRISM estimates and the recorded data sets are most pronounced for data points at elevations greater than 4,000 ft. The largest absolute differences for both the NWS and WRCC data sets coincide with elevation differences of $1,000 \mathrm{ft}$ or more, between the actual station elevation and the average elevation of the PRISM DEM cell. Inherent problems are associated with comparing a point estimate, whether for precipitation or for station elevation, with the average for a coarse grid cell such as the PRISM DEM or precipitation estimate. The problem is accentuated for cells in areas with varied topography, as is often the case with climate stations located in or near areas of extensive topographic relief. This may explain the increased difference between the PRISM estimates and the recorded data sets for stations in the 5,500-7,500 ft elevation zone. In the recorded data set, stations located in this elevation range account for about 48 percent of all the stations. Although the average percent difference between PRISM and the WRCC and the NWS stations in this elevation range is +5 to +7 percent, the range for the differences is from about -60 percent to +100 percent. This is particularly true for the WRCC stations, where about 25 percent of the stations have differences exceeding 15 percent, whereas several exceeded 50 percent. Differences for the WRCC data set may be accentuated by the use of 30-yr averages that do not, in fact, reflect 30 years of data. When compared to the NWS data, where the normals are computed from measured 30-yr periods of record, the PRISM estimates are acceptable for most of the sites.

Comparison of the NRCS SNOTEL 1971-2000 averages to the 1971-2000 PRISM estimates for the same period indicates that, with the exception of six sites, the PRISM precipitation estimates are within 15 percent of the SNOTEL data. Stations with differences greater than 15 percent are those stations whose elevations differ by more than 10 percent from the PRISM DEM elevations. For example, the elevations for SNOTEL stations, Hole-in-Mountain, Mt. Rose Ski, and Ward Mountain differ by more than 1,700; 1,000; and 2,400 ft respectively, whereas PRISM underestimates precipitation by 60, 42 and 46 percent, respectively.

Although the PRISM DEM elevations correlate to the NED 30-m resolution, the PRISM regression equations use the "effective terrain height" grid, which models large-scale topographic features. The terrain height grid is proprietary and was not available for this analysis, thus comparisons to the 4-km DEM grid to determine PRISM elevation accuracy for individual cells or station points may not be appropriate.

Several of the individual sites mentioned in the text and displayed as anomalous areas on the contour maps have location errors. Some other stations, like Sand Pass with over 100 percent difference and no apparent input errors, may exhibit a localized weather pattern not modeled accurately with the large-scale terrain features of PRISM. Large differences between the PRISM data and the WRCC recorded data also may be the result of discrepancies in the period of record used to compute the 30-yr averages. In general, the difference between the PRISM estimates and the recorded data increases as the PRISM estimate increase. Overall, PRISM tends to underestimate precipitation in the $0-10 \mathrm{in}$. range and overestimate in the 15-30 in. range. This might correspond to low precipitation areas having lower elevations. The effective terrain grid-mapping technique used by PRISM may smooth out the lower elevation zones to accentuate prominent 3D terrain features. Precipitation-elevation functions were developed initially from sites located on relatively low elevation, gentle slopes, which are well represented by the PRISM DEM grid (Daly and others, 1994). Extrapolation of the precipitationelevation functions using the effective terrain grid (developed from the 4-km DEM data set) to higher elevation ridges may lead to underestimating precipitation if the effective terrain grid does not resolve localized elevation gradients. Given the small number of high-elevation sites in Nevada, it is difficult to evaluate whether the currently available PRISM precipitation estimates have addressed this potential error.

For HAs in central Nevada with valley floor elevations less than 5,000 ft, PRISM estimates are within 10 percent of estimates made using the Hardman map (Berger, 2001a). Conversely, for HAs in eastern Nevada where baseline elevations tend to exceed 7,000 ft and have mountainous areas that exceed 9,000 ft, estimates typically are 20 percent higher than the precipitation estimates made using the Hardman map (Eakin, 1961, 1967; Rush and Everett, 1966; Glancy, 1968; Harrill, 1970; VanDenburgh and Rush, 1974). The maximum amount of precipitation in the digital Hardman precipitation zones does not exceed 20 in., even in the mountainous areas, thereby accentuating the difference in those HAs with high elevation zones. 


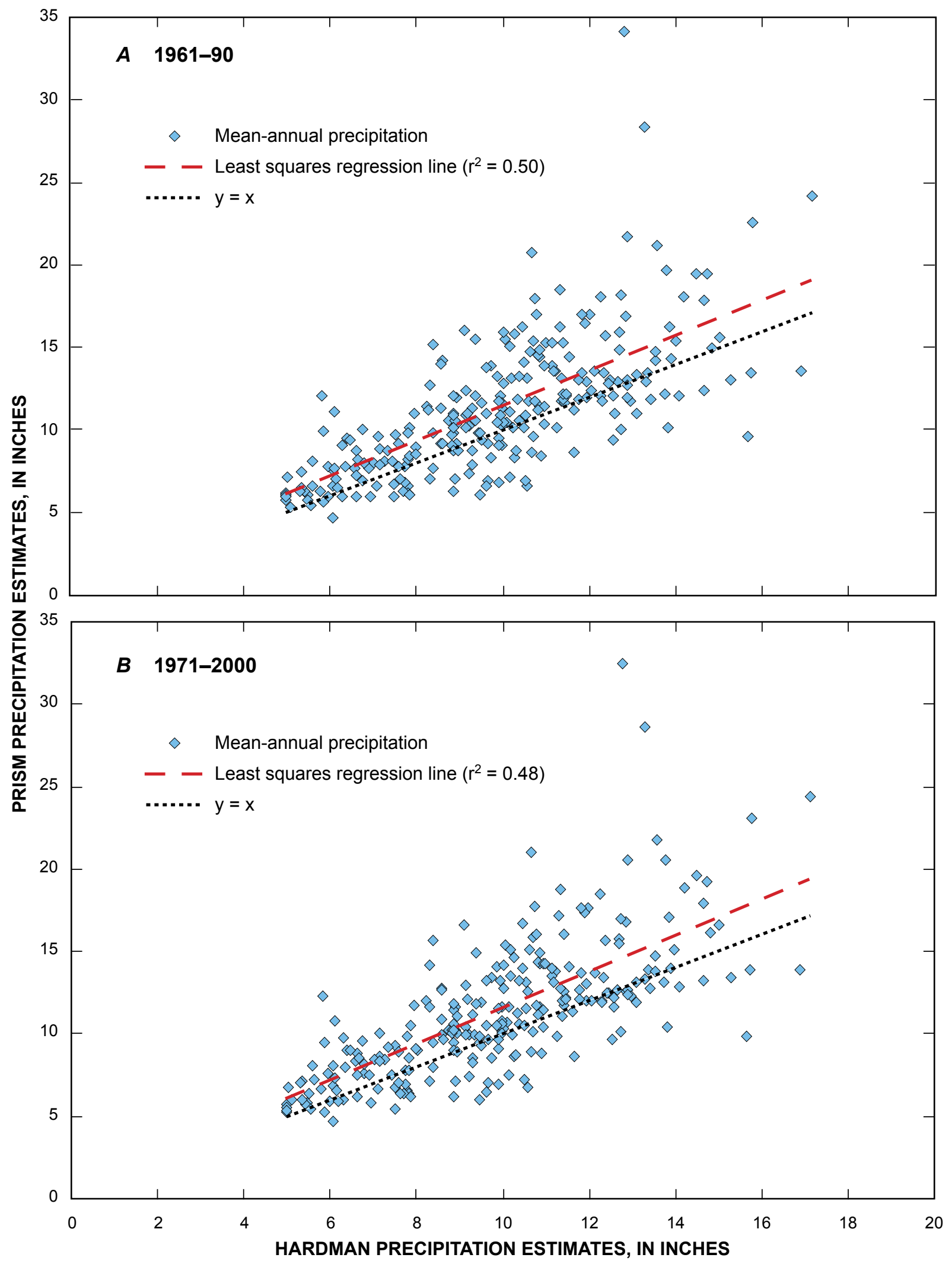

Figure 13. Scatter plots showing relation between Hardman estimates of annual precipitation calculated for hydrographic areas in Nevada and PRISM estimates for 1961-90 and 1971-2000. 


\section{Summary and Conclusions}

The Oregon Climate Service estimated precipitation in the State of Nevada for two 30-year periods, 1961-90 and 1971-2000, using PRISM, a linear precipitation-elevation regression computer model. PRISM precipitation is a simulated (or modeled) estimate based on several parameters within a statistical-geographic framework. Parameters include elevation, topographic orientation (aspect), inversion layers, and proximity to climate stations. PRISM estimates of precipitation are an average over 4-kilometer grid cells. Precipitation can be estimated at a spatial resolution no better than one half the resolutions of the cell, or 2 kilometers in the case of the PRISM data set (Oregon Climate Service, 2004b). The density of most climate networks resolves only large-scale (greater than 10 kilometers) orographic effects and, for this reason, the overall distribution of PRISM precipitation features is more representative of large-scale orographic features.

The intent of the PRISM model is not to specifically match simulated precipitation amounts to recorded station data, but rather to model large-scale orographic processes. This allows for interpolation to locations beyond the recorded data set assuming those locations have similar physiographic and climatic properties. The PRISM documentation does not provide prediction error relative to the station record and, in addition, NWS, WRCC, and NRCS do not provide accuracy ratings for the recorded data at the climate stations. Consequently, for this report a difference of \pm 15 percent relative to the recorded data was selected as an acceptable range of error.

In comparing the two 30-year periods climatologically, the 1961-90 period has a mix of negative and positive Pacific Decadal Oscillations, a decadal-scale pattern of climate variability that are more representative for long-term analyses. The precipitation data used in the development of PRISM, referred to as control points, is proprietary and has not been released to the public. Thus, there is uncertainty in what sources and periods of record were used, whether the data was modified to account for incomplete or poor data, and how the 30-year period mean was computed. The locations of the control points were plotted against known climate station locations, resulting in 64 percent of the control points corresponding to the known sites. Of the total 209 control points, 67 points correspond to NWS sites with 30-year normals for the 1961-90 period, and 92 points correspond to sites with 30 -year normals for the 1971-2000 period. The remaining points referenced stations with shorter periods of record, did not correspond to any point, or were assumed to reference a "pseudo-station" where precipitation estimates are from sources other than recorded measurements. The recorded data sets include the NWS normals and the WRCC 30-yr averages. The WRCC average for many sites represents a 30-year mean computed from mean daily values for the actual period of record within the two time periods.

The NWS normals are considered to be the most accurate reporting of the 30-year means for both the 1961-90 and the
1971-2000 periods. Perhaps not coincidentally, the best correlation of PRISM data with the recorded data sets appears to be using the NWS 1961-90 data set. For the 1961-90 period, the PRISM estimates are within 10 percent of the NWS estimates for 59 of the 67 sites, and 62 sites are within 15 percent. Absolute differences between the PRISM and the NWS precipitation estimates are, on average, less than an inch for most of the State. The range in difference between the PRISM and the WRCC data set is from -3 inches to +3 inches, with a few points exceeding $10 \mathrm{in}$. This difference is significant, particularly for areas that receive less than 8 inches per year. Sixtythree percent of the PRISM estimates were within 15 percent of the WRCC recorded data for the 1961-90 period, and 70 percent were within 15 percent for the 1971-2000 period. PRISM estimates of precipitation are within 15 percent for all but six of the SNOTEL sites used in this study. Some of the error may be attributed to differences between the actual station elevation and the PRISM elevation for the cell containing the station. For those SNOTEL sites where the two elevations match or are close, and the difference exceeds 50 percent, the PRISM precipitation-elevation regression may not accurately model precipitation.

There appears to be little correlation between differences in precipitation estimates and latitude and longitude. Scatter plots of absolute and percent differences relative to the PRISM estimates indicate a slight trend towards increased differences with increased precipitation estimates. In most of the State, the PRISM estimates are within \pm 15 percent of the recorded values for the NWS and the WRCC stations for both of the 30 -year periods, although there are anomalously high and low areas. The differences for interpolated areas between the data points are not be interpreted literally, for these areas cover wide and varied topographic areas. The maps should not be used to adjust point data or make inferences about areas where recorded precipitation is absent. This method of interpolation uses only the available point data, thus the areas between the station sites are interpolated without considering topography and orographic effects. The mapped distribution of differences between the PRISM data and the recorded data are possibly the result of over interpolation between the limited data points, input error in location and station elevation, and the limitations of applying linear regression models where nonlinear relations exist.

The differences between the recorded precipitation and the PRISM estimates are positively correlated to the difference between actual station elevation and the PRISM elevation for the cell containing the station. The largest absolute differences for both the NWS and WRCC data sets coincide with elevation differences of $1,000 \mathrm{ft}$ or more. The spread in differences increases noticeably between the 4,500-8,000 ft range for both NWS and WRCC data.

Comparisons of volume estimates of precipitation by hydrographic area made using the Hardman (1965) data and the PRISM data for both 30 -yr periods indicate that PRISM underestimates HA precipitation volumes in the middle part of the State by as much as 37 percent. For HAs in the northeast- 
ern region and some HAs in the southeastern region, PRISM estimates are within 5 percent of the Hardman estimates. Mean annual precipitation for these HAs range on average from 6 to 13 in. For much of the State outside the central region, PRISM estimates are from 6 to 155 percent greater than Hardman estimates. Typically, PRISM estimates correlate best with Hardman volumes for those HAs with elevations in the 4,000 to $9,000 \mathrm{ft}$ range.

The Oregon Climate Service plans to revise the PRISM map for the State of Nevada and to increase the resolution of the PRISM data set to 900-meter cells. Errors in location and station elevation identified during this and other studies have been provided to OCS. Currently the precipitation-elevation relations developed to distribute precipitation may not be appropriate for all mountainous areas, particularly for leeward slopes. The coarseness of the PRISM grid cells, the sparseness of the long-term precipitation data, and the broad range of differences between the PRISM estimates and the recorded data suggest that the optimum use for this data set is for large-scale studies where long-term averages are required. It is beyond the scope of this study to suggest at precisely what scale of application the PRISM data set might apply, particularly for water budget studies. However, for watershed-scale studies, developing basin-specific precipitation-elevation relations from representative climate stations (ideally in or near the study basin) may be more appropriate.

\section{References Cited}

Berger, D.L., 2000a, Water-budget estimates for the 14 hydrographic areas in the middle Humboldt River Basin, northcentral Nevada: U.S. Geological Survey Water-Resources Investigations Report 00-4168, 55 p.

Berger, D.L., 2000b, Water budgets for Pine Valley, Carico Lake Valley, and Upper Reese River Valley Hydrographic Areas, middle Humboldt River Basin, north-central Nevada-Methods for estimation and results: U.S. Geological Survey Water-Resources Investigation Report 99-4272, $40 \mathrm{p}$.

Cayan, D.R., 1996, Interannual climate variability and snow pack in the western United States: Journal of Climate, v. 9, p. 928-948.

Cardinalli, J.L., Roach, L.M., Rush, F.E., and Vasey, B.J., 1968, State of Nevada hydrographic areas: Nevada Division of Water Resources map, scale 1:500,000

Daly, Christopher, 1998, Variable influence of terrain on precipitation patterns: Delineation and Use of Effective Terrain Height in PRISM, accessed March 16, 2005, at URL http://www.ors.oregonstate.edu/index.html
Daly, Christopher, Neilson, R.P., and Phillips, D.L., 1994, A statistical-topographic model for mapping climatological precipitation over mountainous terrain: Journal of Applied Meteorology, v. 33, no. 2, p. 140-158.

Dettinger, M.D., and Schaefer, D.H., 1995, Decade-scale hydroclimatic forcing of ground-water levels in the central Great Basin, Eastern Nevada-Water Resources and Environmental Hazards: Emphasis on Hydrologic and Cultural Insight in the Pacific Rim, American Water Resources Association, June 1995, p. 195-204.

Dettinger, M.D., Cayan, D.R., Diaz, H.F., and Meko, D.M., 1998, North-south precipitation patterns in Western North America on interannual-to-decadal time scales: Journal of Climate, v. 11, p. 3095-3111.

Dettinger, M.D., Redmond, Kelly, and Cayan, D.R., 2004, Winter orographic precipitation ratios in the Sierra Nevada-Large-scale atmospheric circulations and hydrologic consequences: Journal of Hydrometeorology, v. 5, p. 1102-1116.

Eakin, T.E., 1961, Ground-water appraisal of Pine Valley, Eureka and Elko Counties, Nevada: Nevada, Department of Conservation and Natural Resources, Ground-water Resources - Reconnaissance Report 2, 41 p..

Eakin, T.E., Moore, D.O., and Everett, D.E., 1965, Water resources appraisal of the Upper Reese River Valley, Lander and Nye Counties, Nevada: Nevada Department of Conservation and Natural Resources, Water Resources - Reconnaissance Report 31, 47 p.

Glancy, P.A., 1968, Water-resources appraisal of Butte Valley, Elko and White Pine Counties, Nevada: Nevada Department of Conservation and Natural Resources, Ground-Water Resources - Reconnaissance Report 49, 50 p.

Hardman, George, and Mason, H.G., 1949, Irrigated lands in Nevada: University of Nevada, Reno, Agricultural Experiment Station Bulletin 183, 57 p.

Hardman, George, 1965, Nevada precipitation map, adapted from map prepared by George Hardman, Victor Kral, and others, 1936: University of Nevada, Reno, Agricultural Experiment Station Bulletin 185, 27 p.

Harrill, J.R., 1973, Evaluation of the water resources of Lemmon Valley, Washoe County, Nevada, with emphasis of effects of ground-water development to 1971: Nevada Division of Water Resources Bulletin 42, 130 p.

Harrill, J.R., and Monroe, D.O., 1970, Effects of groundwater development on the water regime of Paradise Valley, Humboldt County, Nevada, 1948-68, and hydrologic reconnaissance of the tributary areas: Nevada Division of Water Resources Bulletin 39, 123 p. 
Helsel, D.R., and Hirsch, R.M., 1992, Statistical methods in water resources: Elsevier Science Publishers, New York, $522 \mathrm{p}$.

Houghton, J.G., Sakamoto, C.M., and Gifford, R.M., 1975, Nevada's climate and weather: Nevada Bureau of Mines and Geology Special Publication 2, 78 p.

Mantua, N.J., Hare, S.N., Zhang, Yuan, Wallace, J.M., and Francis, R.C., 1997, A Pacific interdecadal climate oscillation with impacts on salmon production: Bulletin of the American Meteorological Society, v. 78, p. 1069-1079.

Maxey, G.B., and Eakin, T.E., 1949, Ground water in White River Valley, White Pine, Nye, and Lincoln Counties, Nevada: Nevada State Engineer, Water Resources Bulletin $8,53 \mathrm{p}$.

National Oceanic and Atmospheric Administration, 2005, What is an El Nino?: accessed July 2005 at http:/www. pmel.noaa.gov/tao/elnino/el-nino-story.htm

National Oceanic and Atmospheric Administration, 2005, Explanation of the Palmer Drought Severity Index: accessed June 2005 at http:/Www.cpc.ncep.noaa.gov/products/analysis_monitoring/cdus/palmer_drought

National Weather Service, 2002, United States Normals, 1971-2000 Inhomogeneity Adjustment Methodology: accessed March 2005 at http://www.dnr.sc.gov/climate/ sercc/climateinfo/historical/normnws0320.pd

National Weather Service, 2005, What is the COOP Program: accessed March 2005, at http:/hws.noaa.gov/om/coop/what-is-coop.htm

Natural Resources Conservation Service, 2005, SNOTEL Precipitation Table-Monthly Data Previous Water Years: accessed June 2005 at http://www.wcc.nrcs.usda.gov/cgibin state-site.pl? report $=$ precsnotelmon

Nichols, W.D., 2000, Regional ground-water evapotranspiration and ground-water budgets, Great Basin, Nevada: U.S. Geological Survey Professional Paper 1628, 82 p.

Oregon Climate Service, 2004a, Nevada Average Monthly or Annual Precipitation, 1961-90: accessed April 2004, at http://www.ocs.orst.edu/pub/maps/Precipitation/Total States/NV/nv_rast_meta.htm

Oregon Climate Service, 2004b, PRISM Products: accessed April, 2004 at http:/www.ocs.orst.edu/prism/products

Philip, G.M., and Watson, D.F., 1982, A precise method for determining contoured surfaces: Australian Petroleum Exploration Association Journal, v. 22, p. 205-212.
Rush, F.E., and Kazmi, S.A.T., 1965, Water resources appraisal of Spring Valley, White Pine and Lincoln Counties: Nevada Department of Conservation and Natural Resources, Ground-Water Resources - Reconnaissance Report 33, 36 p.

Rush, F.E., 1968, Index of hydrographic areas in Nevada: Nevada Division of Water Resources, Information Report 6, $38 \mathrm{p}$.

Stockton, E.L., Jones, C.Z., Rowland, R.C., and Medina, R.L., 2003, Water resources data, Nevada, Water Year 2003: U.S. Geological Survey Water-Data Report NV-03-1, 678 p.

VanDenburgh, A.S., and Rush, F.E., 1974, Water-resources appraisal of Railroad and Penoyer Valleys, east-central Nevada: Nevada Department of Conservation and Natural Resources, Ground-Water Resources - Reconnaissance Report 60, 60 p.

Western Regional Climate Center, 2004, Western U.S. Climate Historical Summaries: accessed April 2004, at http:/Wwww. wrcc.dri.edu/summaryd

Western Regional Climate Center, 2005a, Average Statewide Precipitation for Western U.S. States: accessed March 2005: at http:/www.wrcc.dri.edu/htmlfiles/avgstate.ppt.html

Western Regional Climate Center, 2005b, Climate of Nevada, 2005: accessed March, 2005, at http:/www.wrcc.dri.edu/narratives/NEVADA.htm

World Meteorological Organization, 1989, Calculation of monthly and annual 30-year standard normals: WCDP-No. 10, WMO-TD/no. 341, Geneva, World Meteorological Organization. 


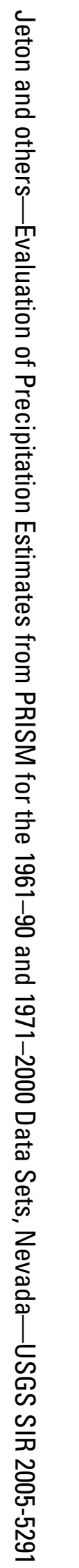

